\title{
Discovery and evaluation of triple inhibitors of VEGFR-2, TIE-2 and EphB4 as anti-angiogenic and anti-cancer agents
}

\author{
Lin Zhang ${ }^{1, *}$, Yuanyuan Shan' ${ }^{2, *}$, Xingyue $\mathrm{Ji}^{3}$, Mengyuan Zhu ${ }^{3}$, Chuansheng $\mathrm{Li}^{1}$, \\ Ying Sun ${ }^{1}$, Ru Si ${ }^{1}$, Xiaoyan Pan ${ }^{1}$, Jinfeng Wang ${ }^{1}$, Weina $\mathrm{Ma}^{1}$, Bingling Dai ${ }^{1}$, Binghe \\ Wang $^{3}$ and Jie Zhang ${ }^{1}$ \\ ${ }^{1}$ School of Pharmacy, Health Science Center, Xi'an Jiaotong University, Xi'an, China \\ 2 Department of Pharmacy, The First Affiliated Hospital of Xi'an Jiaotong University, Xi'an, Shaanxi, China \\ ${ }^{3}$ Department of Chemistry and Center for Diagnostics and Therapeutics, Georgia State University, Atlanta, Georgia, United \\ States \\ * These authors contributed equally to this work and should be regarded as joint first authors \\ Correspondence to: Jie Zhang, email: zhj8623@xjtu.edu.cn
}

Binghe Wang, email: wang@gsu.edu

Keywords: receptor tyrosine kinase, multiple inhibitors, anti-angiogenic agents, anti-cancer agents, quinazolin-4(3H)-one Received: June 15, $2017 \quad$ Accepted: July 30, 2017

Published: August 08, 2017

Copyright: Zhang et al. This is an open-access article distributed under the terms of the Creative Commons Attribution License 3.0 (CC BY 3.0), which permits unrestricted use, distribution, and reproduction in any medium, provided the original author and source are credited.

\section{ABSTRACT}

Receptor tyrosine kinases (RTKs), especially VEGFR-2, TIE-2, and EphB4, play a crucial role in both angiogenesis and tumorigenesis. Moreover, complexity and heterogeneity of angiogenesis make it difficult to treat such pathological traits with single-target agents. Herein, we developed two classes of multi-target RTK inhibitors (RTKIs) based on the highly conserved ATP-binding pocket of VEGFR-2/ TIE-2/EphB4, using previously reported BPS-7 as a lead compound. These multitarget RTKIs exhibited considerable potential as novel anti-angiogenic and anticancer agents. Among them, QDAU5 displayed the most promising potency and selectivity. It significantly suppressed viability of EA.hy926 and proliferation of several cancer cells. Further investigations indicated that QDAU5 showed high affinity to VEGFR-2 and reduced the phosphorylation of VEGFR-2. We identified QDAU5 as a potent multiple RTKs inhibitor exhibiting prominent anti-angiogenic and anticancer potency both in vitro and in vivo. Moreover, quinazolin-4(3H)-one has been identified as an excellent hinge binding moiety for multi-target inhibitors of angiogenic VEGFR-2, Tie-2, and EphB4.

\section{INTRODUCTION}

Pathological angiogenesis is widely involved in tumor progression and has been recognized as a defining characteristic of cancers [1]. Solid tumor growth depends on the vascular vessels to supply oxygen and nutrients and its progression is accompanied with rich angiogenesis [2]. The understanding of angiogenesis has given rise to novel treatment options for cancers. Anti-angiogenic agents are effective in suppressing tumor growth and metastasis [3]. Cancer cells secrete various pro-angiogenic factors such as vascular endothelial growth factors (VEGFs) and its receptor (VEGF Receptor-2, VEGFR-2), angiopoietin (Ang) and its receptor (tyrosine kinase with Ig and epidermal growth factor homology domain-2, Tie-2), erythropoietin-producing hepatoma receptor B4 (EphB4) and its membrane-associated ligand, ephrinB2 [4-6]. However, it is a known fact that many anti-angiogenic agents have failed in the clinic trials. Recently, mounting evidence indicates that tumors become refractory or even bypass the inhibition of a single pro-angiogenic factor via compensatory activation of alternative pro-angiogenic factors [7]. Therefore, systemic characterization of compensatory activation profile constitutes critical steps towards a rational design of multi-target anti-angiogenesis agents. Thus, we undertook the effort to design inhibitors capable of inhibiting multiple targets critical for angiogenesis. 


\section{DESIGN STRATEGY OF MULTI-TARGET RTK INHIBITORS}

We are interested in the discovery of novel anti-angiogenesis agents. Along this line, structural optimization of natural alkaloid taspine afforded a salicylaldoxime including BPS-7 as potent VEGFR-2 inhibitors (Figure 1D) [8-10]. Very importantly, BPS7 displayed potent inhibition against angiogenic EphB4 and Tie-2 [11]. These findings encouraged us to develop novel triple inhibitors of VEGFR-2/TIE-2/EphB4 as antiangiogenic and anticancer agents. Moreover, structural similarity and the highly conserved conformations of VEGFR-2, Tie-2, and EphB4 offer the possibility of designing multi-target inhibitors [12]. The highly conserved aspartate-phenylalanine-glycine (DFG-motif) triad activation loop is essential for kinase activity [13]. Moreover, there is a substantial degree of compensatory activation among three RTKs [14-18]. Therefore, simultaneous inhibition of them might be a promising approach for the suppression of angiogenesis. This kind of multiple RTKIs have a major advantage of overcoming the compensatory feedback of the single-target angiogenesis inhibitors. The three angiogenic RTKs share a basic architecture for construction (Figure 1A-1C), namely hydrogen bonds with the hinge region, hydrophobic interactions with the gatekeeper region, hydrogen bonds with the conserved Glu and DFG motifs and hydrophobic interactions with the allosteric site [19].

Previously, diaryl urea compound BPS-7 was identified as privileged scaffold. Our continuous efforts focused on the development of novel anti-angiogenic agents based on the binding mode of BPS-7 to RTKs. In doing so, we dissected the lead into four regions for optimization work (Figure 2). First, we explored various heteroaromatics as hinge binding group (HBG) via corerefining approach. Pyridine and quinazolin-4(3H)-one were introduced as new HBG. We reasoned that it is possible that these groups could form hydrogen bonds with RTKs and therefore provide an opportunity to improve affinity. Second, the two methoxyl groups on biphenyl of BPS-7 were removed to reduce the steric hindrance in binding with the respective receptor. Third, inspired by the classic bioisosteric paradigm, urea moiety was replaced with thiourea which bears hydrogen bond donors and acceptors. Fourth, various anilines bearing halogen were incorporated as they are beneficial for antitumor potency and could enhance the persistence [20]. In addition, other anilines containing tert-butyl or benzo[ $[d][1,3]$ dioxole were also incorporated as fragments interacting with selective site of RTKs.

These two series of compounds were synthesized, and evaluated for their ability to inhibit RTKs, and then subsequently for their anti-angiogenic and anticancer properties. The representative QDAU5 bearing a quinazolin-4(3H)-one moiety displayed prominent antiangiogenic and anticancer potency both in vitro and in vivo.

\section{RESULTS AND DISCUSSION}

\section{Chemistry}

Scheme 1 depicts the synthesis of diaryl thiourea derivatives DATU1-10. Various commercial available anilines 1 were treated with $\mathrm{CS}_{2}$ to generate 2, which was treated with bis(trichloromethyl)carbonate (BTC) to afford isothiocyanates 3 . The key intermediate 6 was prepared from 3-pyridinylboronic acid 4 and para-bromoaniline 5 by Pd-catalyzed Suzuki coupling reaction without further purification. Finally, these isothiocyanates 3 were reacted with biphenyl intermediates 6 to afford the title compounds DATU1-10.

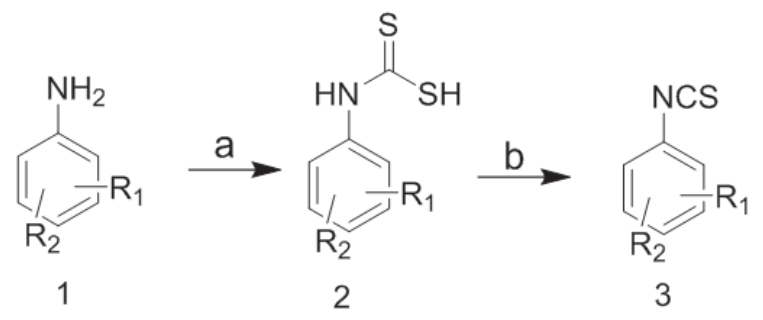

DATU1: $\mathrm{R}_{1}=3-\mathrm{CF}_{3}, \quad \mathrm{R}_{2}=5-\mathrm{Br} \quad$ DATU7: $\mathrm{R}_{1}=3-\mathrm{F}, \quad \mathrm{R}_{2}=4-\mathrm{F}$

DATU2: $\mathrm{R}_{1}=2-\mathrm{OCF}_{3}, \quad \mathrm{R}_{2}=4-\mathrm{Br}$ DATU8: $\mathrm{R}_{1}=3-\mathrm{Cl}, \quad \mathrm{R}_{2}=4-\mathrm{Cl}$

DATU3: $\mathrm{R}_{1}=2-\mathrm{Br}, \quad \mathrm{R}_{2}=4-\mathrm{OCF}_{3}$ DATU9: $\mathrm{R}_{1}=3-\mathrm{CF}_{3}, \quad \mathrm{R}_{2}=5-\mathrm{CF}_{3}$

$\begin{array}{ll}\text { DATU4: } \mathrm{R}_{1}=2-\mathrm{OCF}_{3}, & \mathrm{R}_{2}=5-\mathrm{Br} \\ \text { DATU5: } \mathrm{R}_{1}=2-\mathrm{Br}, & \mathrm{R}_{2}=5-\mathrm{OCF}_{3}\end{array}$ DATU10: $\mathrm{R}_{1}, \mathrm{R}_{2}=\begin{gathered}3.0 \\ 4-0\end{gathered}$

1

DATU5: $\mathrm{R}_{1}=2-\mathrm{Br}$,

DATU6: $\mathrm{R}_{1}=2-\mathrm{Cl}, \quad \mathrm{R}_{2}=4-\mathrm{Cl}$

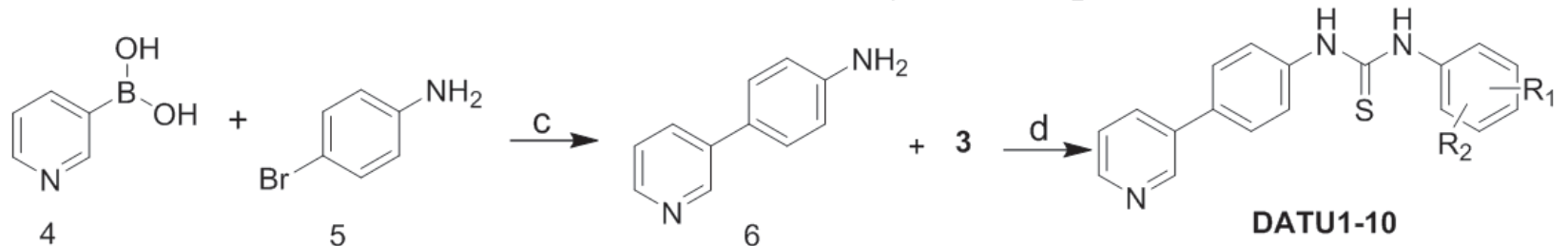

Scheme 1: Synthesis of diaryl thiourea derivatives DATU1-10 ${ }^{a}{ }^{a}$ Reagents and conditions: (a) Dabco, CS 2 , toluene; (b) BTC, DCM; (c) $\mathrm{Pd}\left(\mathrm{PPh}_{3}\right)_{4}, \mathrm{~K}_{2} \mathrm{CO}_{3}$, dioxane, $100^{\circ} \mathrm{C}$; (d) DCM, room temperature. 
Table 1: Structures and RTKs inhibitory activities of title compounds (DATU1-10, IC ${ }_{50}, \mathrm{nM}$ )

\begin{tabular}{|c|c|c|c|c|c|}
\hline Compound & $\mathbf{R}_{1}$ & $\mathbf{R}_{2}$ & VEGFR-2 & TIE-2 & EphB4 \\
\hline DATU1 & $3-\mathrm{CF}_{3}$ & $5-\mathrm{Br}$ & 20.6 & 25.7 & 20.0 \\
\hline DATU2 & $2-\mathrm{OCF}_{3}$ & 4- $\mathrm{Br}$ & $>500$ & 64.2 & $>500$ \\
\hline DATU3 & $2-\mathrm{Br}$ & $4-\mathrm{OCF}_{3}$ & $>500$ & 20.0 & 21.8 \\
\hline DATU4 & $2-\mathrm{OCF}_{3}$ & $5-\mathrm{Br}$ & $>500$ & $>500$ & 18.7 \\
\hline DATU5 & $2-\mathrm{Br}$ & $5-\mathrm{OCF}_{3}$ & $>500$ & $>500$ & 54.2 \\
\hline DATU6 & $2-\mathrm{Cl}$ & $4-\mathrm{Cl}$ & 23.5 & 66.5 & 3.86 \\
\hline DATU7 & $3-\mathrm{F}$ & $4-\mathrm{F}$ & 45.2 & 48.4 & 10.0 \\
\hline DATU8 & $3-\mathrm{Cl}$ & 4-Cl & 354 & 9.40 & $>500$ \\
\hline DATU9 & $3-\mathrm{CF}_{3}$ & $5-\mathrm{CF}_{3}$ & $>500$ & $>500$ & $>500$ \\
\hline DATU10 & \multicolumn{2}{|c|}{$\begin{array}{l}3-0 \\
4-0\end{array}$} & 20.40 & $>500$ & $>500$ \\
\hline Sorafenib & & & 0.55 & 4.65 & 3.00 \\
\hline
\end{tabular}

The synthetic route of quinazolinone diaryl urea derivatives QDAU1-10 is shown in Scheme 2. 2-Amino5-bromobenzoicacid 7 was converted to intermediate 8 by cyclization with formamide under atmospheric microwave heating at $150^{\circ} \mathrm{C}$. The coupling substrates 10 were obtained by condensation of amino-boronate 9 with various isocyanates, which were prepared from reaction of anilines with BTC. Subsequently, the title commands QDAU1-10 were prepared from the key intermediates 8 and 10 by Suzuki coupling reaction (See Supplementary Materials).

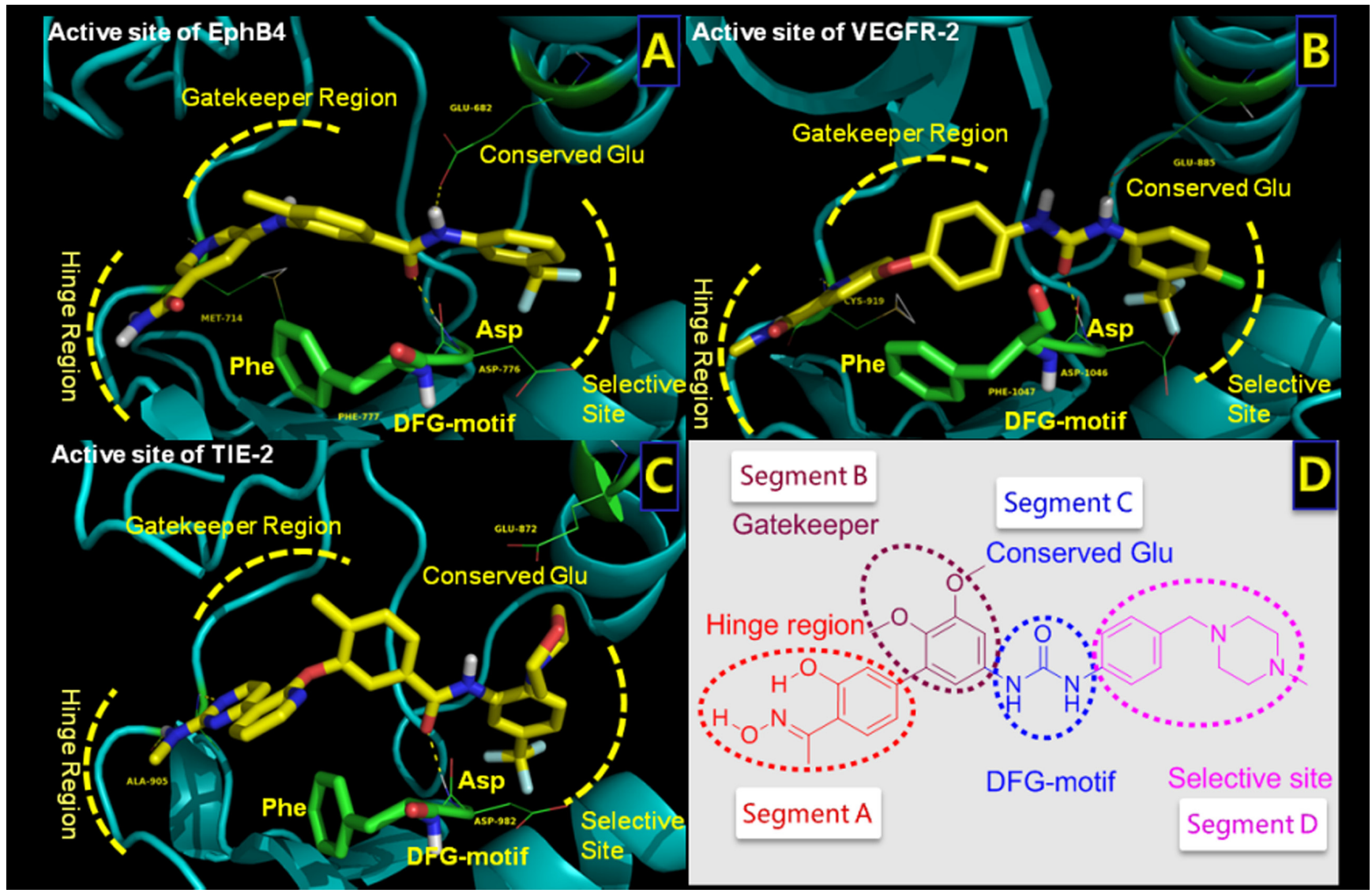

Figure 1: Structures of the active sites of three RTKs bound with co-crystalized inhibitors. A. Structure of EphB4 complexed with 32W (PDB ID: 4BB4). B. Structure of VEGFR-2 bound with sorafenib (PDB ID: 4ASD). C. Structure of Tie-2 complexed with MR9 (PDB ID: 2P4I). D. Structure and pharmacophore of lead compound (BPS-7). Critical elements of inhibitor interaction are labeled and highlighted. 
Table 2: Structures and RTKs inhibitory activities of title compounds (QDAU1-10, IC $\left.{ }_{50}, \mathrm{nM}\right)$

\begin{tabular}{|l|c|c|c|c|c|}
\hline \multicolumn{1}{|c|}{ Compound } & $\mathbf{R}_{\mathbf{1}}$ & $\mathbf{R}_{\mathbf{2}}$ & VEGFR-2 & Tie-2 & EphB4 \\
\hline QDAU1 & $\mathrm{H}$ & $3-\mathrm{CF}_{3}$ & 194 & 70.5 & $>500$ \\
\hline QDAU2 & $\mathrm{H}$ & $3-\mathrm{Cl}$ & 57.9 & 83.9 & $>500$ \\
\hline QDAU3 & $\mathrm{H}$ & $3-\mathrm{F}$ & $>500$ & 90.7 & 5.64 \\
\hline QDAU4 & $\mathrm{H}$ & $2-\mathrm{F}$ & 1.91 & 4.91 & 13.9 \\
\hline QDAU5 & $3-\mathrm{F}$ & $4-\mathrm{F}$ & 0.77 & 8.87 & 3.21 \\
\hline QDAU6 & $\mathrm{H}$ & $4-\mathrm{F}$ & 6.28 & 101 & $>500$ \\
\hline QDAU7 & $\mathrm{H}$ & $4-\mathrm{OCF}_{3}$ & $>500$ & 258 & $>500$ \\
\hline QDAU8 & $\mathrm{H}$ & $-\mathrm{CH}_{3}\left(\mathrm{CH}_{3}\right)_{2}$ & 41.5 & $>500$ & $>500$ \\
\hline QDAU9 & $4-\mathrm{Cl}$ & $3-\mathrm{CF}_{3}$ & 15.8 & 19.6 & 24.4 \\
\hline QDAU10 & $\mathrm{H}$ & $4-\mathrm{CF}_{3}$ & 50.7 & 52.7 & $>500$ \\
\hline Sorafenib & & & 0.55 & 4.65 & 3.00 \\
\hline
\end{tabular}

Table 3: RTKs selectivity profile of the most active compounds $\left(\mathrm{IC}_{50}, \mathrm{nM}\right)$

\begin{tabular}{|l|c|c|c|c|c|c|c|}
\hline Compound & VEGFR-1 & PDGFR- $\beta$ & FGFR-1 & FGFR-4 & B-Raf & EGFR & c-Kit \\
\hline QDAU4 & 68.3 & $>500$ & 165.9 & 83.4 & 136 & 113 & $>500$ \\
\hline QDAU5 & 192 & 98.5 & 176.2 & $>500$ & $>500$ & 98.8 & 142 \\
\hline
\end{tabular}

\section{Biological evaluation}

The three targeted RTKs are involved in both angiogenesis and tumorigenesis [21]. With the aim of developing anti-angiogenic and anticancer agents, we firstly evaluated the title compounds for their inhibitory effect and selectivity among various RTKs. Subsequently, in order to validate the dual function of the title compounds, their inhibition on viability of human endothelial cells (HECs, EA.hy926) was examined to examine the anti-angiogenic potency. In addition, their binding affinity to angiogenic RTKs and anticancer potency were also studied in different models. A marketed multi-target RTK inhibitor, sorafenib, was used as positive control.

\section{In Vitro receptor tyrosine kinases inhibition assay}

In order to validate the direct effect of title compounds on VEGFR-2, Tie-2, and EphB4 kinases, we performed in vitro assay using the ADP-Glo Kinase Assay Kit (Promega, Wisconsin, USA). In analyzing the inhibition data, we first look at the implications of replacement with thiourea and the hinge binding group of BPS-7. Meanwhile, pyridine was introduced as hinge binding groups (Table 1). It was obvious that compounds with $d i$-halogen substituents (DATU6-8) were more potent than the others. DATU6 displayed the most potent RTKs inhibitory activities with $\mathrm{IC}_{50}$ values of $23.5 \mathrm{nM}$ (VEGFR-2), 66.5nM (Tie-2), and $3.86 \mathrm{nM}$ (EphB4), respectively.

Encouraged by the promising potency of diaryl ureas, we chose to continue our structural optimization by keeping urea unit constant. Quinazolin-4(3H)-one

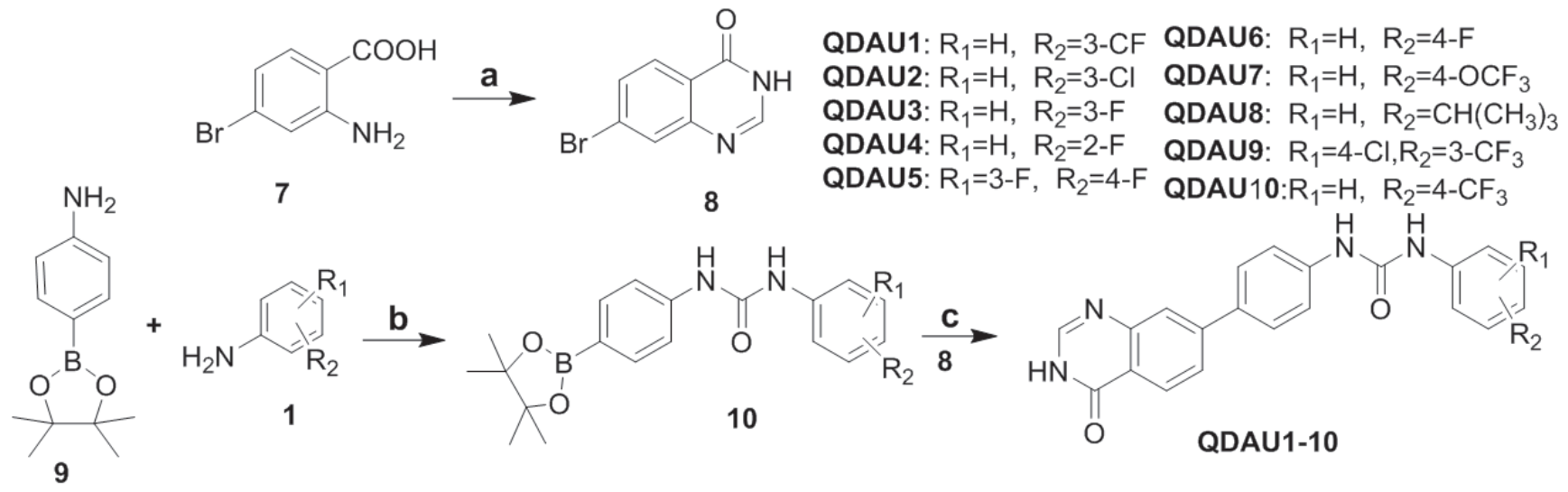

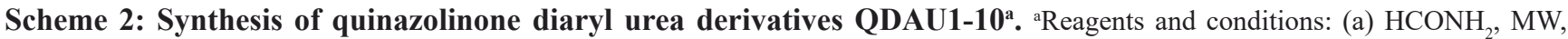
$150^{\circ} \mathrm{C}, 1.5 \mathrm{~h}$; (b) BTC, $\mathrm{Et}_{3} \mathrm{~N}, 0^{\circ} \mathrm{C}$ to room temperature; (c) $\mathrm{Pd}\left(\mathrm{PPh}_{3}\right)_{4}, \mathrm{~K}_{2} \mathrm{CO}_{3}, \mathrm{H}_{2} \mathrm{O} /$ dioxane, $100^{\circ} \mathrm{C}$. 
was incorporated onto diaryl urea core as a novel hinge binding group of multi-target inhibitors (Table 2). Three title compounds (QDAU4, QDAU5, QDAU9) displayed simultaneous inhibitory potency against VEGFR-2, Tie-2, and EphB4. In particular, QDAU5 bearing a 3,4-difluoroanilinegroup was the most potent multi-target RTKs inhibitors with $\mathrm{IC}_{50}$ values of $0.77 \mathrm{nM}$ (VEGFR-2), $8.87 \mathrm{nM}$ (Tie-2), and 3.21 nM (EphB4), respectively. The results highlight the importance of the quinazolin-4(3H)one moiety for improving the inhibition of these multiple inhibitors. This study identified that quinazolin-4(3H)one was an excellent hinge binding group for multi-target inhibitors of VEGFR-2, Tie-2, and EphB4.

\section{Kinase selectivity assays}

We investigated the kinase selectivity of the two most potent compounds (QDAU4, QDAU5) against other seven kinases including VEGFR-1, VEGFR-3, FGFR-1, FGFR-4, B-Raf, EGFR and c-Kit for its selective profile. The results were summarized in Table 3. The results revealed that they showed less potency against these RTKs compared with VEGFR-2, TIE-2, and EphB4 with $\mathrm{IC}_{50}$ values higher than $50 \mathrm{nM}$. It was indicated that they exhibited moderate selectivity for VEGFR-2/TIE-2/EphB4 relative to other RTKs.

\section{Effects on the viability of human endothelial cells (HECs)}

In order to determine the anti-angiogenic effect of these multi-target inhibitors, we evaluated their effect on HECs (EA.hy926) viability using cell counting kit-8 (CCK-8) method [22]. Highly consistent with their potent RTKs inhibitory activity, the majority of the selected compounds displayed dose-dependent inhibition of EA.hy926 viability with $\mathrm{IC}_{50}$ values ranging from $4.00 \mu \mathrm{M}$ to $255 \mu \mathrm{M}$ (Table 4). Notably, three compounds (DATU1, QDAU4, and QDAU5) exhibited more potent inhibition on the viability of HECs than the others with $\mathrm{IC}_{50}$ values less than $10 \mu \mathrm{M}$. These results demonstrated that these compounds could display anti-angiogenic potency through decreasing viability of HECs (EA.hy926). In addition, we profiled the most potent compound, QDAU5, in the anti-proliferative assays against human normal cells. We identified the cytotoxicity of QDAU5 on normal human liver cells (QSG7701) and human embryonic kidney 293 (HEK293). In summary, the results indicated that QDAU5 displayed selective growth inhibition of EA.hy 926 over two human normal cells $\left(\mathrm{IC}_{50}\right.$ values $\left.>100 \mu \mathrm{M}\right)$. From this we might conclude that the representative QDAU5 exhibit selective growth inhibitory activity against HECs compared to normal human cell lines.

\section{Apoptosis detection assay}

To further investigate the effect of QDAU5 on the apoptosis of HECs (EA.hy926), we performed flow cytometry analysis and apoptosis detection assays. A substantial and dose-dependent proapoptotic activity in HECs at various concentrations for $48 \mathrm{~h}$ was observed. The apoptotic EA.hy926 cells $(10.35 \%)$ of negative control group were depicted in Figure 3A. After treatment with QDAU5 $(5,20$, and $40 \mathrm{nM})$ for $48 \mathrm{~h}$, the percentage

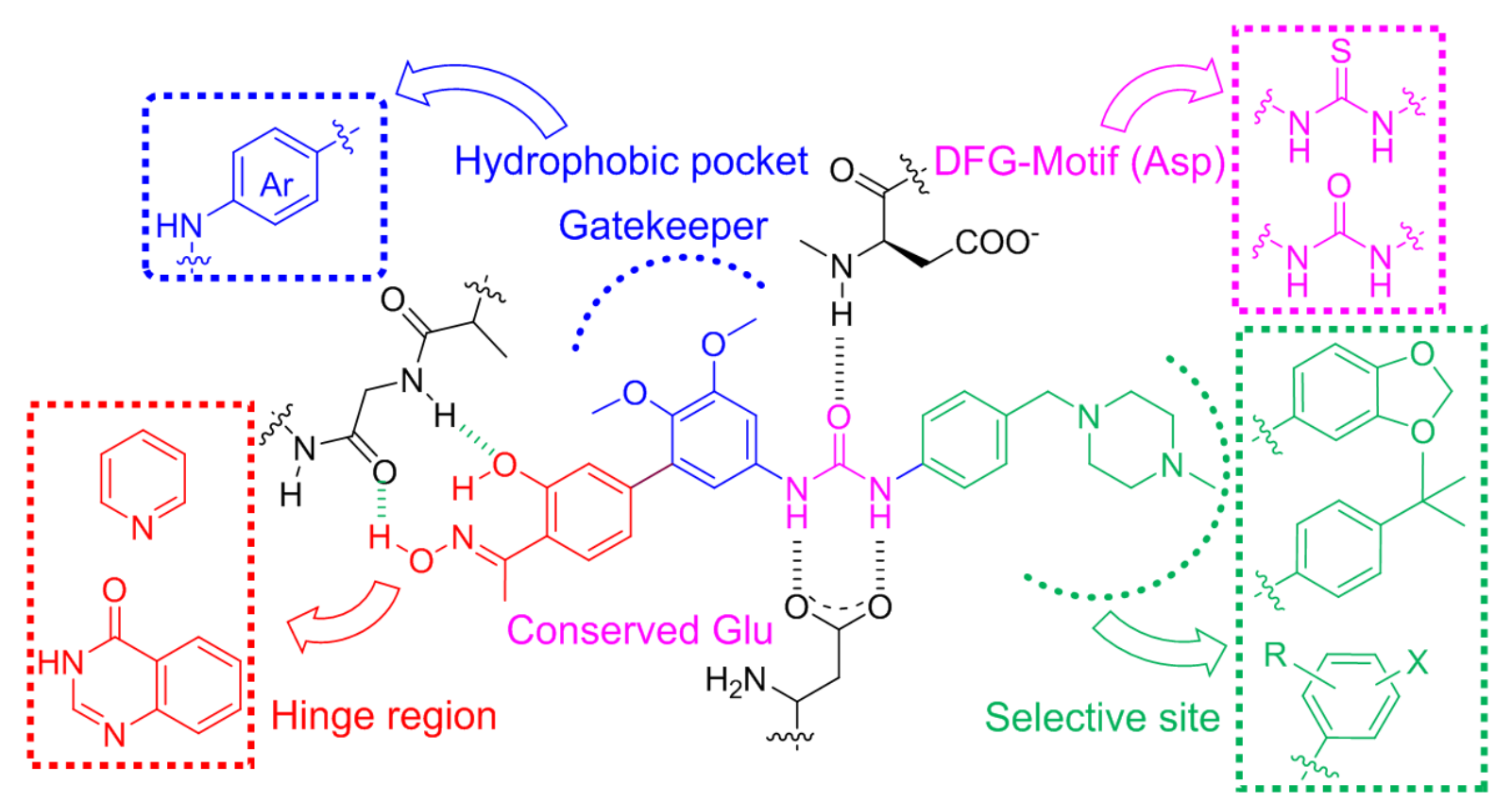

Figure 2: Design strategy and structures of novel multi-target anti-angiogenesis agents derived from BPS-7. 
of early apoptotic cells was 19.55\%, 28.35\%, 31.43\%, respectively (Figure 3B-3D). The results indicate that QDAU5 could induce early apoptosis of HECs (EA. hy926) in a dose dependent manner.

\section{Anti-proliferative activity against cancer cells}

These RTKs play critical roles in the proliferation of various cancers. Therefore, RTKs inhibition generally translate well into anti-proliferation activity. In this regard, in order to investigate the potential anticancer potency of these multi-target RTKs inhibitors, the most potent inhibitor, QDAU5, was selected to examine its anti-proliferative activity against a panel of cancer cell lines including human hepatic cancer cell lines (7721), human breast cancer cell lines (MCF-7), human pancreatic cancerous cell lines (PANC-1), human epidermoid carcinoma cell line (A431), human lung cancer cell (A549), human colon carcinoma cell line (LOVO), and
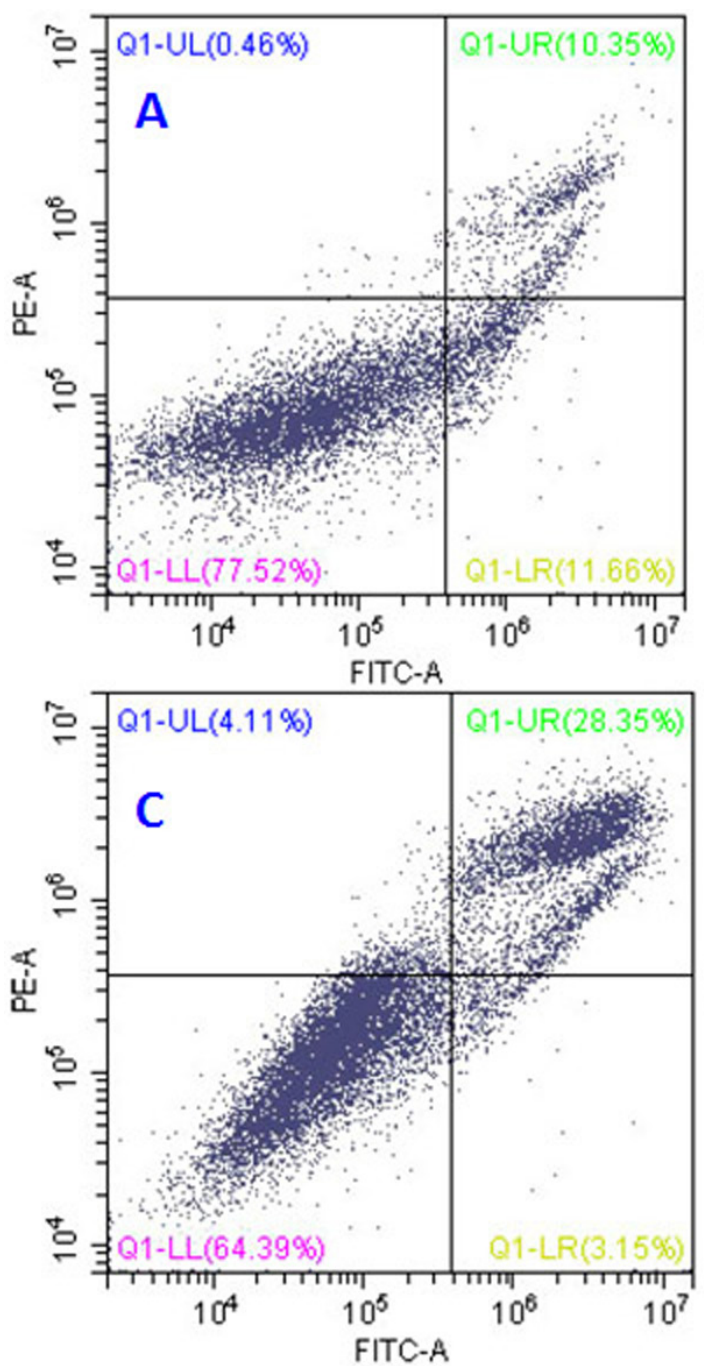

human cervical cancer cell line (HeLa). QDAU5 was found to significantly inhibit the growth of all seven cancer cell lines with $\mathrm{IC}_{50}$ values ranging from $2.12 \mu \mathrm{M}$ to $24.9 \mu \mathrm{M}$ (Table 5). In summary, QDAU5 displayed significant anti-proliferative activity against a broad spectrum of cancer cell lines. In addition, we identified the cytotoxicity of QDAU5 on two normal cell lines (QSG7701 and HEK293). Overall, the results indicated that QDAU5 exhibited selective growth inhibition of human cancer cell lines over two human normal cells $\left(\mathrm{IC}_{50}\right.$ values $\left.>100 \mu \mathrm{M}\right)$. From this we might conclude that the representative QDAU5 displayed selective growth inhibitory potency against all eight human cancer cell lines compared to normal human cell lines.

Because of it potent inhibition of RTKs and antiproliferative activity, QDAU5 was further evaluated for its in vivo anticancer properties in a MCF-7 xenograft mice model [23]. QDAU5 treatment was initiated when tumors were palpable and continued for 21 days. In the MCF7 xenograft model, QDAU5 could cause a significant
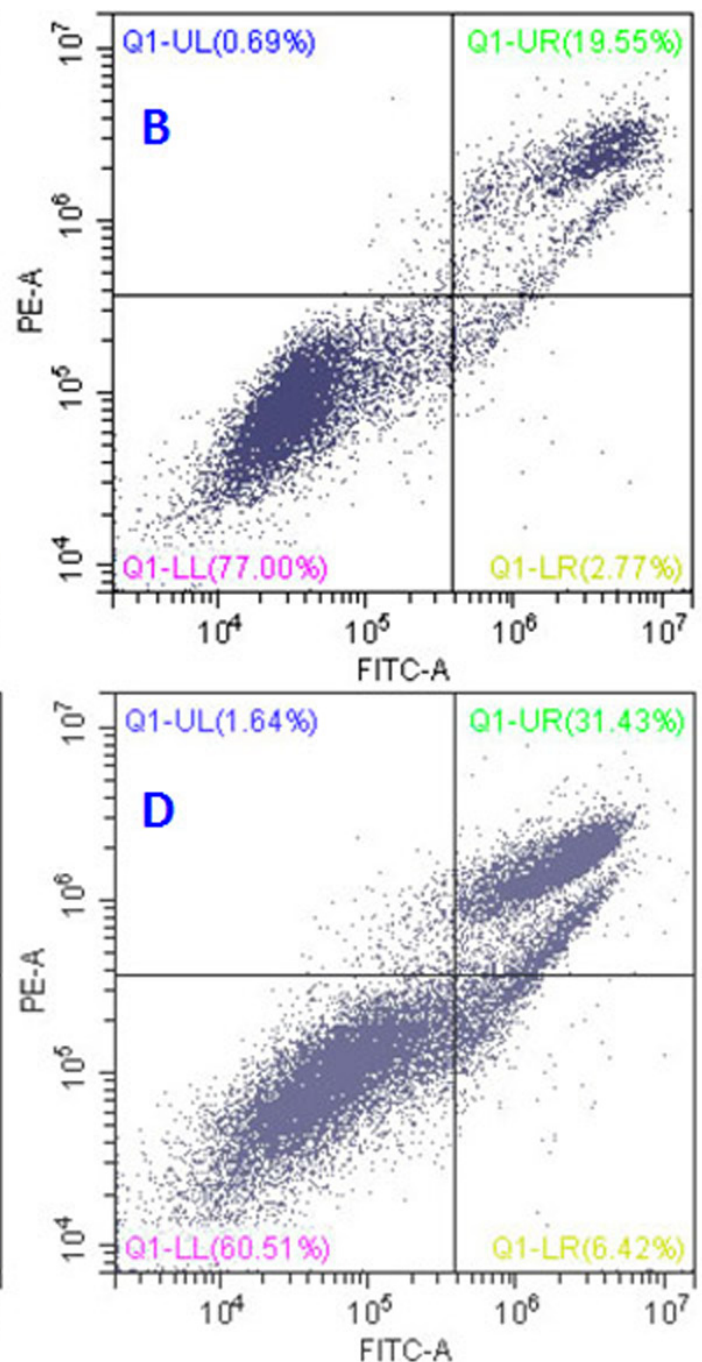

Figure 3: Apoptosis detection assays of EA.hy 926 cells after treatment with QDAU5 (A, 0 nM; B, 5 nM; C, 20 nM; D $40 \mathrm{nM})$. 
Table 4: Inhibition of compounds on human endothelial cell viability $\left(\mathrm{IC}_{50}, \mu \mathrm{M}\right)$

\begin{tabular}{|l|c|c|c|c|c|}
\hline \multicolumn{1}{|c|}{ Compound } & EA.hy926 & Compound & EA.hy926 & Compound & EA.hy926 \\
\hline DATU1 & 3.96 & DATU8 & 102 & QDAU5 & 2.69 \\
\hline DATU2 & 89.9 & DATU9 & 166 & QDAU6 & 255 \\
\hline DATU3 & 122 & DATU10 & 90.6 & QDAU7 & 68.5 \\
\hline DATU4 & 44.8 & QDAU1 & 57.9 & QDAU8 & 76.2 \\
\hline DATU5 & 246 & QDAU2 & 66.3 & QDAU9 & 13.0 \\
\hline DATU6 & 24.4 & QDAU3 & 42.6 & QDAU10 & 125 \\
\hline DATU7 & 96.4 & QDAU4 & 8.64 & Sorafenib & 16.5 \\
\hline
\end{tabular}

Table 5: Anti-proliferative activity of QDAU5 against human cancer and normal cells (IC $\left.{ }_{50}, \mu \mathrm{M}\right)$

\begin{tabular}{|l|c|c|c|c|c|c|c|c|c|}
\hline Cell line & $\mathbf{7 7 2 1}$ & MCF-7 & PANC-1 & A431 & A549 & LOVO & HeLa & QSG7701 & HEK293 \\
\hline QDAU5 & 58.7 & 2.12 & 24.9 & 16.9 & 8.37 & 4.99 & 5.56 & $>100$ & $>100$ \\
\hline
\end{tabular}

Table 6: Anticancer potency of QDAU5 in mouse xenograft models

\begin{tabular}{|l|c|c|c|c|c|c|}
\hline \multirow{2}{*}{ Treatment } & Route & Dose (mg/kg) & $\begin{array}{l}\text { Initial body weight } \\
\mathbf{( g )}\end{array}$ & $\begin{array}{l}\text { Final body weight } \\
(\mathbf{g})\end{array}$ & $\begin{array}{l}\text { Final } \\
\text { weight }(\mathbf{g})\end{array}$ & $\begin{array}{l}\text { tumor } \\
\text { inhibition (\%) }\end{array}$ \\
\hline Control & ig & 0 & $17.7 \pm 0.7$ & $16.6 \pm 0.8$ & $0.848 \pm 0.5$ & $/$ \\
\hline \multirow{3}{*}{ QDAU5 } & ig & 20 & $18.7 \pm 0.8$ & $17.4 \pm 1.0$ & $0.787 \pm 0.7$ & $7.2 \%$ \\
\cline { 2 - 8 } & ig & 40 & $18.4 \pm 0.6$ & $18.9 \pm 1.2$ & $0.642 \pm 0.8$ & $24 \%$ \\
\cline { 2 - 8 } & ig & 80 & $18.3 \pm 0.7$ & $16.1 \pm 1.0$ & $0.449 \pm 0.9$ & $47 \%$ \\
\hline Sorafenib & ig & 40 & $19.5 \pm 0.9$ & $16.8 \pm 0.9$ & $0.398 \pm 0.8$ & $53 \%$ \\
\hline
\end{tabular}

reduction of tumor weight in a dose dependent manner (Table 6). Compared with the control group, QDAU5 inhibited tumor growth by $24 \%$ and $47 \%$ at $40 \mathrm{mg} / \mathrm{kg}$ and $80 \mathrm{mg} / \mathrm{kg}$, respectively. Moreover, less body weight loss and no other abnormities were observed in the QDAU5treated mice compared with controls. Such results indicate that QDAU5 is non-toxic at the doses used. It can be concluded that QDAU5 exhibited active anticancer activity with little signs of toxicity.

\section{Identification of QDAU5 binding to VEGFR-2 by cell membrane chromatography method}

The cell membrane chromatography (CMC) method has been developed as a new bioaffinity chromatographic system and been widely used to identify potent RTK inhibitors [24]. In previous studies, artificial cultures highly expressing VEGFR-2 on HEK293 cell lines were constructed. A novel analytical method coupling highexpression VEGFR-2/CMC with high performance
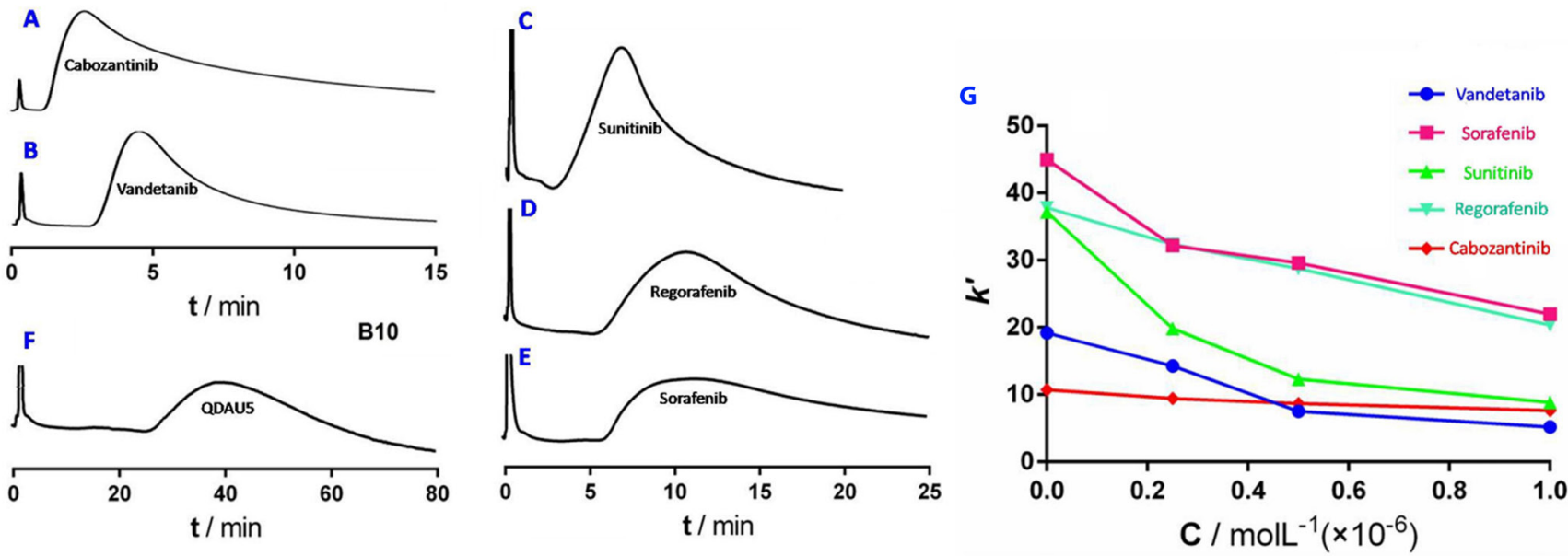

Figure 4: Elution profiles of cabozantinib (RT=2.6 min). A., vandetanib (RT=4.5 min) B., sunitinib (RT=6.8 $\mathrm{min})$ C., regorafenib $(\mathrm{RT}=10.6 \mathrm{~min}) \mathbf{D}$., sorafenib $(\mathrm{RT}=11.4 \mathrm{~min}) \mathbf{E}$. and QDAU5 $(\mathrm{RT}=38.0 \mathrm{~min}) \mathbf{F}$. on the VEGFR-2/cell membrane stationary phase column. Chromatographic conditions: $10 \mathrm{~mm} \times 2.0 \mathrm{~mm}$; flow rate $0.6 \mathrm{~mL} / \mathrm{min}$; column temperature $37^{\circ} \mathrm{C}$; mobile phase $5 \mathrm{mM}$ PBS, pH 7.4 ; detection wavelength $270 \mathrm{~nm}$. G. Change in retention factors of multi-target RTK inhibitors $\left(K^{\prime}\right)$ in the presence of QDAU5 with increased concentrations as direct competitor in the mobile phase. 
Table 7: Different residues of three RTKs (VEGFR-2, Tie-2, EphB4)

\begin{tabular}{|c|c|c|c|}
\hline \multicolumn{4}{|c|}{ Different residues of three proteins } \\
\hline Index in VEGFR-2 & VEGFR-2 & Tie-2 & EphB4 \\
\hline 892 & I & $\mathrm{L}$ & $\mathrm{F}$ \\
\hline 916 & $\mathrm{~V}$ & I & $\mathrm{T}$ \\
\hline 919 & $\mathrm{C}$ & $\bar{A}$ & $\mathrm{M}$ \\
\hline 1045 & $\overline{\mathrm{C}}$ & $\overline{\mathrm{A}}$ & $\mathrm{S}$ \\
\hline
\end{tabular}

liquid chromatography model was applied to identify ligands acting on VEGFR-2 specifically, and investigate the affinity of QDAU5 to VEGFR-2 [25]. The elution profiles of five multi-target RTKs inhibitors (cabozantinib, vandetanib, sunitinib, regorafenib and sorafenib) and QDAU5 on the high-expression VEGFR-2/CMC model are shown in Figure 4. It was found that the retention times of the inhibitors and QDAU5 were very different from each other. QDAU5 showed a longer retention time of 38 min while the retention time of the potent VEGFR-2 inhibitors, regorafenib and sorafenib, were both $11 \mathrm{~min}$. One can reasonable assume that the retention on the VEGFR-2/CMC model is largely dependent on binding with VEGFR-2. In addition, the retention behavior of

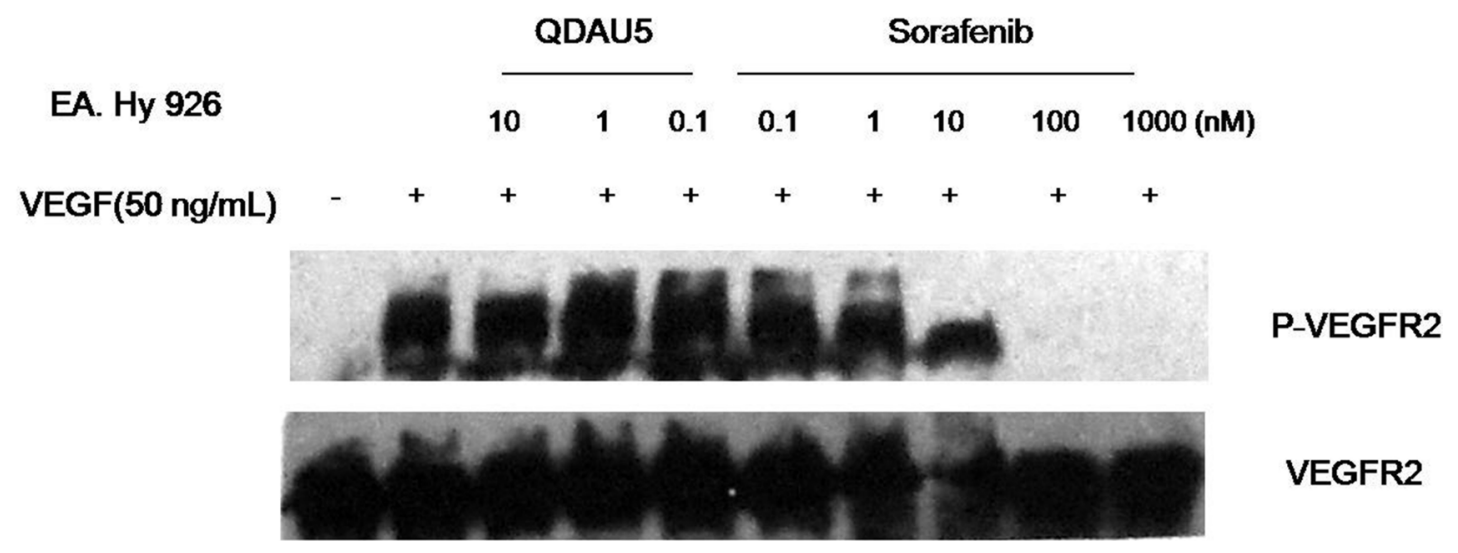

Figure 5: Effect of QDAU5 on the level and phosphorylation of VEGFR-2 in EA.hy926 cells.

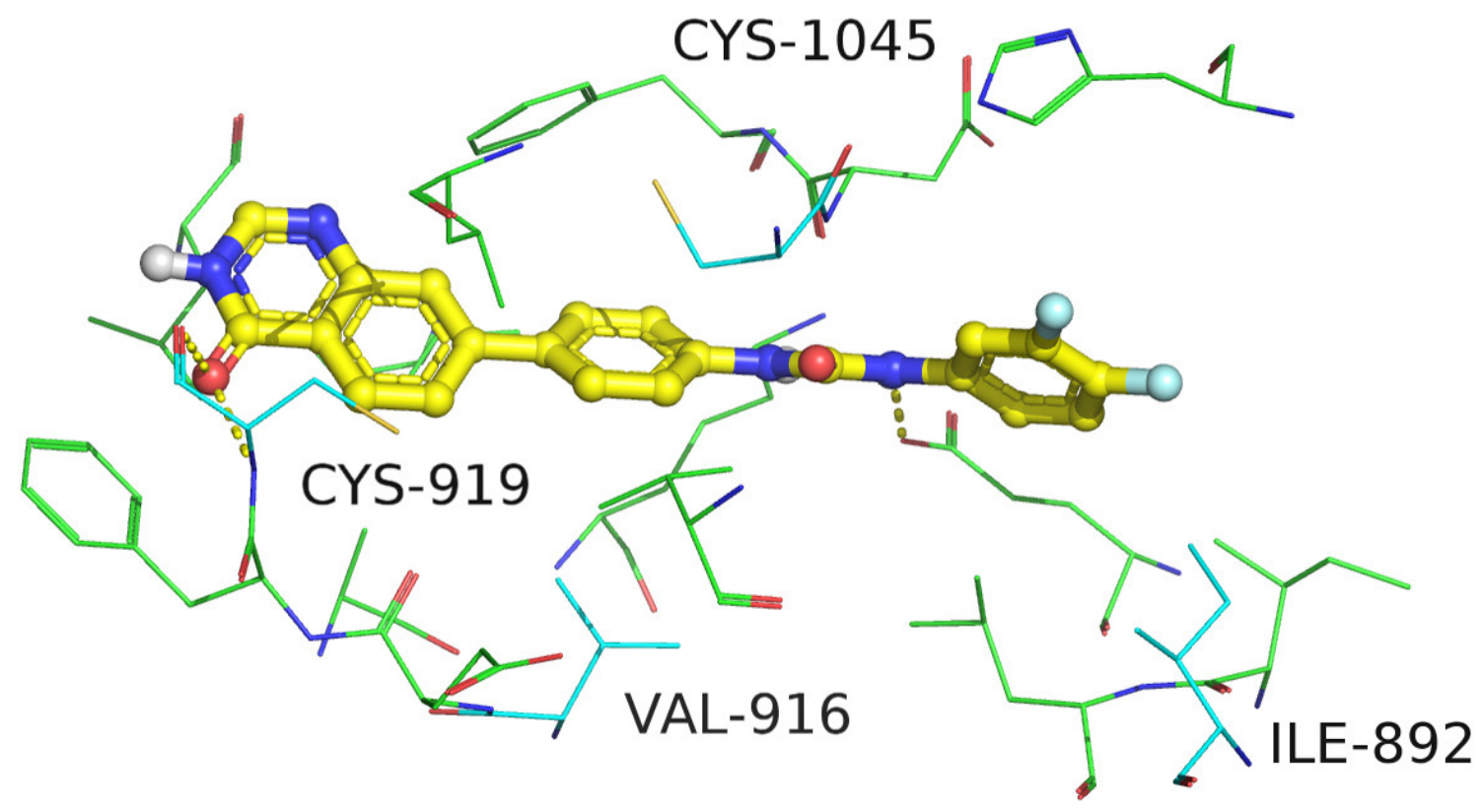

Figure 6: Docked molecule QDAU5 (yellow sticks) and residues within $4 \AA$ in the crystal structure of VEGFR-2. Residues that are same or in the same classes are colored in green while different residues are colored in cyan. 
QDAU5 on the VEGFR-2/CMC column indicate that QDAU5 exhibited higher affinity than these multi-target inhibitors when binding toVEGFR-2.

In the direct competitive assay, five multi-target RTKIs and QDAU5 were used as competitors to examine the competition between known inhibitors and QDAU5 when binding with VEGFR-2 [26]. Figure 4G shows the change in retention factors of multi-target RTKs inhibitors $\left(K^{\prime}\right)$ in the presence of QDAU5 at different concentrations as a direct competitor in the mobile phase. Decreased $K$ 'values of multi-target RTKs inhibitors was observed with increasing concentrations of QDAU5 in the mobile phase. The displacement studies indicated that QDAU5 interacted with the same site of VEGFR-2 with that of the five multi-target RTKIs.

We further evaluated the effect of representative QDAU5 on the expression level and phosphorylation of VEGFR-2 in HECs using western blot assay. EA.hy926 cells were treated with QDAU5 for $48 \mathrm{~h}$ followed by 50 $\mathrm{ng} / \mathrm{mL}$ VEGF stimulation for $10 \mathrm{~min}$. It was found that QDAU5 dose-dependently decreased VEGF-induced tyrosine phosphorylation of VEGFR-2 in EA.hy926 cells compared with the negative control group (Figure 5). In addition, it moderately reduced the level of VEGFR-2 in VEGF-stimulated EA.hy926 cells. Our findings suggested that the influence of QDAU5 on cell viability of EA.hy926 might be attributed to the inhibition of phosphorylation of VEGFR-2.These results suggested that QDAU5 might exhibit anti-angiogenic and anti-cancer potency by inhibiting VEGFR-2 activation.

To gain a better understanding of its interaction with RTKs, molecular docking was conducted with the crystal structure of VEGFR-2. Besides, the different residues of three proteins were picked out for further analysis (Table 7). As we can see in Figure 6, QDAU-5 forms hydrogen bonding interactions with the side chain of the conserved Glu885 and the backbone of Cys979. For the four different residues, because it is the backbone of Cys979 to interact with the inhibitor, its side chain does not affect much. Second, the closet distances between inhibitor and Ile

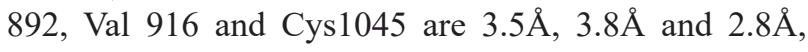
respectively, so they don't greatly change the pocket. Our docking result may explain why QDAU5 shows activities on all three proteins.

\section{MATERIALS AND METHODS}

\section{Biological evaluation}

\section{In vitro angiogenic $\mathrm{RTKs}$ inhibition assays}

The in vitro RTK inhibition assays against VEGFR-2, TIE-2, and EphB4 of all the title compounds were detected using the ADP-Glo ${ }^{\mathrm{TM}}$ kinase assay kit (Promega, Madison) with sorafenib as a positive control.
The kinase assay was performed in a reaction mixture of final volume of $10 \mu \mathrm{L}$. General procedures are as the following: for VEGFR-2 assays, the tyrosine kinase (0.6 $\mathrm{ng} / \mathrm{mL})$ were incubated with substrates $(0.2 \mathrm{mg} / \mathrm{mL})$, test title compounds $\left(1.2 \times 10^{-4} \sim 12 \mu \mathrm{M}\right)$ and ATP $(50 \mu \mathrm{M})$ in a final buffer of Tris $40 \mathrm{mM}, \mathrm{MgCl}_{2} 10 \mathrm{mM}$, BSA $0.1 \mathrm{mg} /$ $\mathrm{mL}$, DTT $1 \mathrm{mM}$ in 384-well plate with the total volume of $5 \mu \mathrm{L}$. The plate was incubated at $30^{\circ} \mathrm{C}$ for $1 \mathrm{~h}$. After the plate was cooled at room temperature for $5 \mathrm{~min}, 5$ $\mu \mathrm{L}$ of ADP-Glo reagent was added into each well to stop the reaction and consume the remaining ADP within 40 min. At the end, $10 \mu \mathrm{L}$ of kinase detection reagent was added into the well and incubated for $30 \mathrm{~min}$ to produce a luminescence signal. As for TIE-2 and EphB4 assays, the kinase $(2.4 \mathrm{ng} / \mathrm{mL})$ were incubated with substrates $(0.2 \mathrm{mg} / \mathrm{mL})$, tested compounds $\left(1.2 \times 10^{-4} \sim 12 \mu \mathrm{M}\right)$ and ATP $(50 \mu \mathrm{M})$ in a final buffer of Tris $40 \mathrm{mM}, \mathrm{MgCl}_{2} 10$ $\mathrm{mM}$, BSA $0.1 \mathrm{mg} / \mathrm{mL}$, DTT $1 \mathrm{mM}$ in 384-well plate with the total volume of $5 \mu \mathrm{L}$. The assay plate was incubated at $30^{\circ} \mathrm{C}$ for $4 \mathrm{~h}$. After the plate was cooled at room temperature for $5 \mathrm{~min}, 5 \mu \mathrm{L}$ of ADP-Glo reagent was added into each well to stop the reaction and consume the remaining ADP within $1 \mathrm{~h}$. At the end, $10 \mu \mathrm{L}$ of kinase detection reagent was added into each well and incubated for $30 \mathrm{~min}$ to produce a luminescence signal. The luminescence was read by VICTOR-X multi-label plate reader.

\section{In vitro $\mathrm{RTK}$ selectivity assays [27]}

A $50 \mu \mathrm{L}$ reaction mixture contains $40 \mathrm{mM}$ Tris, $\mathrm{pH}$ 7.4, $10 \mathrm{mM} \mathrm{MgCl}, 0.1 \mathrm{mg} / \mathrm{ml} \mathrm{BSA,} 1 \mathrm{mM}$ DTT, $10 \mu \mathrm{M}$ ATP, kinase and substrate $(0.2 \mathrm{mg} / \mathrm{mL}$ Poly(Glu, Tyr $) / 10$ $\mu \mathrm{M}$ ATP). The test compounds were diluted in $10 \%$ DMSO and $5 \mu \mathrm{L}$ of the dilution was added to a $50 \mu \mathrm{L}$ reaction so that the final concentration of DMSO is $1 \%$ in all of reactions. The assay was performed using KinaseGlo Plus luminescence kinase assay kit. It measures kinase activity by quantitating the amount of ATP remaining in solution following a kinase reaction. The luminescent signal from the assay is correlated with the amount of ATP present and is inversely correlated with the amount of kinase activity. The $\mathrm{IC}_{50}$ values were calculated using nonlinear regression with normalized dose-response fit using Prism GraphPad software.

\section{Human endothelial cells (EA.hy926) viability assay [28]}

The viability of HECs (EA.hy926) was assessed using the cell counting kit-8 (CCK-8, Sigma, USA) assay according to the manufacturer's instruction. In brief, EA-hy926 cells were harvested and plated in a 96-wellplate at the density of $1 \times 10^{5}$ cells for each well and cultured in DMEM containing $10 \%$ FBS in humidified $5 \% \mathrm{CO}_{2}$ atmosphere. After incubation at $37^{\circ} \mathrm{C}$ for $48 \mathrm{~h}$, the cells were treated with tested compounds at various concentrations for $24 \mathrm{~h}$. Subsequently, premixed CCK-8 and medium $(10 \mu \mathrm{L})$ were added into the 96 -well plates to monitor cell viability and were incubated at $37{ }^{\circ} \mathrm{C}$ for $2 \mathrm{~h}$. 
The number of viable cells was assessed by measurement of absorbance at $450 \mathrm{~nm}$ by a microplate reader. The viability rate was calculated as experimental OD value/ control OD value.

\section{Apoptosis detection assay [29]}

EA.hy926 cells $\left(5 \times 10^{5}\right.$ cells $\left./ \mathrm{mL}\right)$ were seeded in six-well plates and treated with QDAU5 at different concentrations $(0,5,20$, and $40 \mathrm{nM})$ for $48 \mathrm{~h}$. The cells were then harvested by trypsinization and washed twice with cold PBS. After centrifugation and removal of the supernatants, EA.hy926 cells were re-suspended in 400 $\mu \mathrm{L}$ of $1 \times$ binding buffer which was then added to $5 \mu \mathrm{L}$ of annexin V-FITC and incubated at room temperature for $15 \mathrm{~min}$. After adding $10 \mu \mathrm{L}$ of PI the cells were incubated at room temperature for another $15 \mathrm{~min}$ in the dark. The stained cells were analyzed by a flow cytometer (BD Accuri C6).

\section{Anti-proliferative activity against cancer cell lines}

Anti-proliferative activities of QDAU5 were evaluated against fifteen cancer cell lines using 3-(4,5-dimethylthiazol-2-yl)-2,5-diphenyltetrazolium bromide (MTT) method. Exponentially growing cells were harvested and plated in 96-well plates at a concentration of $1 \times 10^{4}$ cells/well per well, and then were incubated at $37^{\circ} \mathrm{C}$ for $24 \mathrm{~h}$. The cells were treated with QDAU5 at various concentrations for $48 \mathrm{~h}$. Subsequently, $22 \mu \mathrm{L}$ fresh MTT $(5 \mathrm{mg} / \mathrm{mL})$ was added to each well and incubated at $37{ }^{\circ} \mathrm{C}$ for 4 h. $150 \mathrm{~mL}$ DMSO was added to each well after supernatant was discarded. Absorbance values were determined by a microplate reader (Bio-Rad Instruments) at $490 \mathrm{~nm}$. The $\mathrm{IC}_{50}$ values were calculated according to inhibition ratios.

\section{In vivo xenograft model [30]}

Six-week old female BALB/c mice were purchased from Shanghai Laboratory Animal center of the Chinese Academy of Sciences and housed under aseptic and ventilated condition. The mice were inoculated by subcutaneous injection with MCF-7 cancer cells suspended in 5\% saline. Tumor volume and weight were measured on alternate days. Body weights were monitored as an indicator of toxicity. When tumor volume exceeds100 $\mathrm{mm}^{3}$, mice were randomly divided into treatment and control groups ( $\mathrm{n}=8$ per group): QDAU5 and vehicle control $(0.5 \%$ CMC-Na). Treatment groups were administered orally with QDAU5 daily at doses of 20,40 , and $80 \mathrm{mg} / \mathrm{kg}$, respectively. Treatment started from the next day and continued for 21 days. All mice were killed at the end of the experiment, and subcutaneous tumors were removed and weighted.

\section{Western blot analysis}

The expression and phosphorylation of VEGFR-2 in EA.hy926 cells were assessed using western blot analysis with various antibodies. After treatment with QDAU5 at various concentrations for $48 \mathrm{~h}$, EA.hy926 cells were washed twice with ice-cold PBS (137 mM NaCl, $2.7 \mathrm{mM} \mathrm{KCl}, 10 \mathrm{mM} \mathrm{Na}_{2} \mathrm{HPO}_{4}$, and $1.8 \mathrm{mM} \mathrm{KH}_{2} \mathrm{PO}_{4}$, $\mathrm{pH}$ 7.4) and lysed in SDS sample buffer. Cell lysates containing equal amounts of protein were separated by SDS polyacrylamide gel electrophoresis and transferred to polyvinylidene difluoride membranes. After being blocked in 5\% nonfat milk in Tris-buffered saline with $0.1 \%$ Tween $20, \mathrm{pH} 7.6$, the membranes were incubated with the appropriate primary antibodies at $4{ }^{\circ} \mathrm{C}$ overnight and then exposed to secondary antibodies for $2 \mathrm{~h}$ at room temperature. Immunoreactive proteins were visualized using the enhanced chemiluminescence system from Pierce Chemical.

\section{VEGFR-2/CMC evaluation}

The VEGFR-2 cell membrane stationary phase was prepared as previous reported. Aqueous ammonium acetate buffer solution ( $\mathrm{pH} 7.4,5 \mathrm{mM}$ ) was pumped at a flow rate of $0.2 \mathrm{~mL} / \mathrm{min}$ as the mobile phase after VEGFR-2/CMC column was loaded onto the chromatography system at the temperature of $37^{\circ} \mathrm{C}$. The standard solutions of five multi-target RTK inhibitors and QDAU5 were injected to evaluate their affinity with VEGFR-2. The mobile phase was $5.0 \mathrm{mM}$ phosphate burred saline with a $0.6 \mathrm{~mL} / \mathrm{min}$ flow rate at a column temperature of $37^{\circ} \mathrm{C}$. The detected wavelength was $270 \mathrm{~nm}$. The test compound was injected into the VEGFR-2/CMC column and their retention characteristics were identified to evaluate their affinity with VEGFR-2. A direct competitive assay was studied by using QDAU5 as a competitor at different concentrations.

\section{Molecular docking}

The crystal structure (PDBID: 4ASD) of VEGFR-2 was used for docking. The small molecule's 3D structure was optimized with Omega2 $[31,32]$. Docking study was conducted using OEDocking module $\operatorname{FRED}[33,34]$ with default parameters on GSU cluster Orion [35] and XSEDE [36].

\section{General methods for chemistry}

All solvents and reagents were purchased from commercial suppliers and purified according to the standard procedure. The reactions except those in aqueous media were carried out by standard techniques for the exclusion of moisture. All the reactions were monitored 
by thin layer chromatography (TLC) on $0.25-\mathrm{mm}$ silica gel plates (60GF-254) and visualized with UV light. Flash column chromatography was performed using silica gel (300-400 mesh). Melting points were determined using an electrothermal melting point apparatus and were uncorrected. ${ }^{1} \mathrm{H}-\mathrm{NMR}$ and ${ }^{13} \mathrm{C}$-NMR spectra were recorded on a Bruker Advance AC 400 instrument at $400 \mathrm{MHz}$ and $101 \mathrm{MHz}$, respectively. Chemical shift ( $\delta$ ) are reported in parts per million (ppm) with TMS as an internal standard and coupling constants $(J)$ are expressed in hertz $(\mathrm{Hz})$. High resolution mass spectra (HRMS) analysis was performed on a Shimadzu LCMS-IF-TOF instrument. All the title compounds were determined to be $\geq 95 \%$ pure by HPLC analysis which was carried out on a Shimadzu HPLC instrument.

\section{General Procedure for the Synthesis of diarylthiourea derivativesDATU 1-10}

\section{(3-bromo-5-(trifluoromethyl)phenyl) carbamodithioic acid (2)}

3-Bromo-5-(trifluoromethyl) aniline (2.5 g, 10.4 $\mathrm{mmol})$, DABC (1.4 g, $12.5 \mathrm{mmol})$ was dissolved in toluene $(40 \mathrm{~mL})$. Then $1.9 \mathrm{~mL}$ carbon disulphide was added dropwise to the above mixture. Subsequently, the mixture was reacted at room temperature for $8 \mathrm{~h}$. The product was collected by filtration and dried under vacuum to afford 2 as a slight yellow solid (1.2g, 40\%).

\section{1-bromo-3-isothiocyanato-5-(trifluoromethyl)benzene} (3)

Compound 2 (0.8 g, $2.5 \mathrm{mmol})$ was dissolved in anhydrous $\mathrm{CH}_{2} \mathrm{Cl}_{2}(20 \mathrm{~mL})$. Then triphosgene $(0.88 \mathrm{~g}, 3$ mmol) in anhydrous $\mathrm{CH}_{2} \mathrm{Cl}_{2}$ was added dropwise to the above mixture on the ice-bath, and stirring continued for $2 \mathrm{~h}$ at room temperature. After completion of the reaction, the organic layer was washed with water and brine (100 $\mathrm{mL} \times 3$ ), and dried over $\mathrm{Na}_{2} \mathrm{SO}_{4}$. After filtration and concentration in vacuo, the residue was purified by silica gel flash chromatography to afford $3(0.50 \mathrm{~g}, 30.0 \%)$.

\section{4-(pyridin-3-yl)aniline (6)}

A flask charged with $\mathrm{Pd}\left(\mathrm{PPh}_{3}\right)_{4}(3.8 \mathrm{~g}, 3.25 \mathrm{mmol})$, $\mathrm{K}_{2} \mathrm{CO}_{3}$ (13.5 g, $97.5 \mathrm{mmol}$ ), and 4-bromoaniline (9) (5.00 $\mathrm{g}, 29.30 \mathrm{mmol}$ ) and pyridin-3-ylboronic acid (8) (4.0 g, $32.5 \mathrm{mmol}$ ) were flushed with nitrogen and suspended in 1,4-dioxane $(90 \mathrm{~mL})$ and water $(30 \mathrm{~mL})$. The mixture was then refluxed overnight under nitrogen. The hot suspension was filtered and the filtrate distilled by rotary evaporation to remove 1,4-dioxane. Water $(50 \mathrm{~mL})$ was added and the product was extracted with AcOEt $(30 \mathrm{~mL} \times 3)$, washed with water, and dried over $\mathrm{Na}_{2} \mathrm{SO}_{4}$. After filtration and concentration in vacuo, the residue was purified by silica gel flash chromatography $(\mathrm{PE} / \mathrm{AcOEt}=5: 1)$ affording 3 as white solid (2.8 g, 40\%).

\section{N-[3-bromo-5-(trifluoromethyl)phenyl]-N'-(4-pyridin-} 3-ylphenyl)thiourea (DATU1)

The key intermediate 4-(pyridin-3-yl)aniline 6 (0.80 g, $2.84 \mathrm{mmol})$ was dissolved in anhydrous $\mathrm{CH}_{2} \mathrm{Cl}_{2}$ (10 mL).1-Bromo-3-isothiocyanato-5-(trifluoromethyl) benzene 3 in anhydrous $\mathrm{CH}_{2} \mathrm{Cl}_{2}(10 \mathrm{~mL})$ was added dropwise to the above mixture, and stirring on the ice-bath continued for $2 \mathrm{~h}$. After stirring at room temperature for $18 \mathrm{~h}$. The organic layer was washed with water and brine $(100 \mathrm{~mL} \times 3)$, and dried over $\mathrm{Na}_{2} \mathrm{SO}_{4}$. After filtration and concentration in vacuo, the residue was purified by silica gel flash chromatography to yield DATU1 in 50\% yield. HRMS $m / z$ calcd for $\mathrm{C}_{19} \mathrm{H}_{13} \mathrm{BrF}_{3} \mathrm{~N}_{3} \mathrm{~S}\left([\mathrm{M}+\mathrm{H}]^{+}\right)$453.2932, found 453.6968. m.p. $=197-199^{\circ} \mathrm{C},{ }^{1} \mathrm{H}$ NMR (400 MHz, DMSO-d6) $\delta 9.28$ (s, 1H), $9.13(\mathrm{~s}, 1 \mathrm{H}), 8.89$ (d, $J=2.0$ $\mathrm{Hz}, 1 \mathrm{H}), 8.54(\mathrm{~m}, 1 \mathrm{H}), 8.06(\mathrm{~m}, 1 \mathrm{H}), 7.98(\mathrm{~s}, 1 \mathrm{H}), 7.90$ $(\mathrm{s}, 1 \mathrm{H}), 7.70(\mathrm{~d}, J=8.7 \mathrm{~Hz}, 2 \mathrm{H}), 7.62(\mathrm{~d}, J=8.7 \mathrm{~Hz}$, 2H), 7.54 (s, 1H), $7.47(\mathrm{~m}, 1 \mathrm{H}) .{ }^{13} \mathrm{C}$ NMR (101 MHz, DMSO-d6) $\delta 152.73,148.42,147.70,142.59,139.77$, $135.59,133.98,131.53,131.34,127.75,125.02,124.56$, $124.31,122.83,122.30,121.06,119.60,113.97$.

The title compounds DATU2-10 were prepared from the key intermediate 3 and 6 with a similar procedure as described for compound DATU1.

N-[4-bromo-2-(trifluoromethoxy)phenyl]-N'-(4pyridin-3-ylphenyl)thiourea (DATU2).

HRMS $m / z$ calcd for $\mathrm{C}_{19} \mathrm{H}_{13} \mathrm{BrF}_{3} \mathrm{~N}_{3} \mathrm{OS}\left([\mathrm{M}]^{+}\right)$ 466.9915, found 466.9940. m.p. $=144-145^{\circ} \mathrm{C},{ }^{1} \mathrm{H}$ NMR (400 MHz, DMSO-d6) $\delta 10.25$ (s, 1H), 9.65 (s, 1H), 8.92 $(\mathrm{d}, J=2.2 \mathrm{~Hz}, 1 \mathrm{H}), 8.56(\mathrm{~m}, 1.4 \mathrm{~Hz}, 1 \mathrm{H}), 8.11-8.07(\mathrm{~m}$, 1H), $7.76(\mathrm{~s}, 1 \mathrm{H}), 7.74(\mathrm{~m}, 2 \mathrm{H}), 7.70(\mathrm{~s}, 1 \mathrm{H}), 7.66$ (d, J= $8.4 \mathrm{~Hz}, 2 \mathrm{H}), 7.64-7.61(\mathrm{~m}, 1 \mathrm{H}), 7.49(\mathrm{~m}, 1 \mathrm{H}) .{ }^{13} \mathrm{C}$ NMR (101 MHz, DMSO-d6) $\delta 180.72,148.76,147.90,143.48$, $139.67,135.43,134.27,133.71,132.13,131.24,130.90$, 127.46, 124.76, 124.48, 124.36, 121.70, 119.14, 118.57 .

$N$-[2-bromo-4-(trifluoromethoxy)phenyl]-N'-(4pyridin-3-ylphenyl)thiourea (DATU3). HRMS $m / z$ calcd for $\mathrm{C}_{19} \mathrm{H}_{13} \mathrm{BrF}_{3} \mathrm{~N}_{3} \mathrm{OS}\left([\mathrm{M}]^{+}\right)$466.9915, found 469.9937 . m.p. $=162-163^{\circ} \mathrm{C},{ }^{1} \mathrm{H}$ NMR (400 MHz, DMSO-d6) $\delta 10.26$ $(\mathrm{s}, 1 \mathrm{H}), 9.61(\mathrm{~s}, 1 \mathrm{H}), 8.92(\mathrm{~d}, J=1.8 \mathrm{~Hz}, 1 \mathrm{H}), 8.56(\mathrm{~m}$, $1 \mathrm{H}), 8.11-8.06(\mathrm{~m}, 1 \mathrm{H}), 7.80(\mathrm{~d}, J=2.2 \mathrm{~Hz}, 1 \mathrm{H}), 7.76(\mathrm{~d}$, $J=8.7 \mathrm{~Hz}, 2 \mathrm{H}), 7.70(\mathrm{~d}, J=5.1 \mathrm{~Hz}, 2 \mathrm{H}), 7.68(\mathrm{~d}, J=5.3$ $\mathrm{Hz}, 1 \mathrm{H}), 7.51-7.47$ (m, 1H), 7.47-7.43 (m, 1H). ${ }^{13} \mathrm{C}$ NMR (101 MHz, DMSO-d6) $\delta 180.73,148.75,147.89,146.61$, $139.64,138.05,135.44,134.25,133.65,131.87,127.49$, $125.78,124.53,124.36,122.57,121.71,121.08,119.16$.

$N$-[5-bromo-2-(trifluoromethoxy)phenyl]-N'-(4pyridin-3-ylphenyl)thiourea (DATU4). HRMS $m / z$ calcd for $\mathrm{C}_{19} \mathrm{H}_{13} \mathrm{BrF}_{3} \mathrm{~N}_{3} \mathrm{OS}\left([\mathrm{M}]^{+}\right)$466.9915, found 469.9939 . m.p. $=154-155^{\circ} \mathrm{C},{ }^{1} \mathrm{H}$ NMR (400 MHz, DMSO-d6) $\delta 10.34$ (s, 1H), $9.70(\mathrm{~s}, 1 \mathrm{H}), 8.92(\mathrm{~d}, J=2.2 \mathrm{~Hz}, 1 \mathrm{H}), 8.57$ (m, 1.4 $\mathrm{Hz}, 1 \mathrm{H}), 8.11-8.06(\mathrm{~m}, 2 \mathrm{H}), 7.76(\mathrm{~d}, J=8.6 \mathrm{~Hz}, 2 \mathrm{H}), 7.67$ $(\mathrm{d}, J=8.6 \mathrm{~Hz}, 2 \mathrm{H}), 7.54(\mathrm{~m}, 1 \mathrm{H}), 7.49(\mathrm{~m}, 1 \mathrm{H}), 7.41(\mathrm{~m}$, 1H). ${ }^{13} \mathrm{C}$ NMR (101 MHz, DMSO-d6) $\delta$ 180.62, 148.77 , $147.91,142.22,139.57,135.42,134.28,133.97,133.82$, $131.70,130.03,127.49,124.53,124.36,123.44,121.70$, 
119.36, 119.13 .

$N$-[2-bromo-5-(trifluoromethoxy)phenyl]-N'-(4pyridin-3-ylphenyl)thiourea (DATU5). HRMS $\mathrm{m} / \mathrm{z}$ calcd for $\mathrm{C}_{19} \mathrm{H}_{13} \mathrm{BrF}_{3} \mathrm{~N}_{3} \mathrm{OS}\left([\mathrm{M}]^{+}\right) 466.9915$, found 469.9935 . m.p. $=125-126^{\circ} \mathrm{C},{ }^{1} \mathrm{H}$ NMR (400 MHz, DMSO-d6) $\delta 10.38$ $(\mathrm{s}, 1 \mathrm{H}), 9.63(\mathrm{~s}, 1 \mathrm{H}), 8.92(\mathrm{~s}, 1 \mathrm{H}), 8.57(\mathrm{~d}, J=3.3 \mathrm{~Hz}, 1 \mathrm{H})$, $8.10(\mathrm{~d}, J=7.9 \mathrm{~Hz}, 1 \mathrm{H}), 7.83(\mathrm{~d}, J=8.8 \mathrm{~Hz}, 1 \mathrm{H}), 7.76(\mathrm{~d}$, $J=8.5 \mathrm{~Hz}, 2 \mathrm{H}), 7.70(\mathrm{~s}, 2 \mathrm{H}), 7.68(\mathrm{~s}, 1 \mathrm{H}), 7.49(\mathrm{~m}, 1 \mathrm{H})$, $7.25(\mathrm{~d}, J=8.2 \mathrm{~Hz}, 1 \mathrm{H}) \cdot{ }^{13} \mathrm{C}$ NMR (101 MHz, DMSO-d6) $\delta 180.38,148.78,147.91,147.48,139.93,139.47,135.42$, $134.32,134.27,133.77,127.53,124.58,124.37,122.80$, $121.69,120.71,119.87,119.13$.

$N$-(2,4-dichlorophenyl)- $N$ '-(4-pyridin-3-ylphenyl) thiourea (DATU6). HRMS $\mathrm{m} / z$ calcd for $\mathrm{C}_{18} \mathrm{H}_{13} \mathrm{Cl}_{2} \mathrm{~N}_{3} \mathrm{~S}$ $\left([\mathrm{M}+\mathrm{H}]^{+}\right)$374.0207, found 374.0257. m.p. $=156-157^{\circ} \mathrm{C}$, ${ }^{1} \mathrm{H}$ NMR (400 MHz, DMSO-d6) $\delta 10.23$ (s, 1H), 9.63 (s, $1 \mathrm{H}), 8.91(\mathrm{~d}, J=1.9 \mathrm{~Hz}, 1 \mathrm{H}), 8.56(\mathrm{~m}, 1 \mathrm{H}), 8.11-8.07(\mathrm{~m}$, $1 \mathrm{H}), 7.75(\mathrm{~d}, J=8.6 \mathrm{~Hz}, 2 \mathrm{H}), 7.71(\mathrm{~d}, J=2.3 \mathrm{~Hz}, 1 \mathrm{H})$, $7.67(\mathrm{~d}, J=8.6 \mathrm{~Hz}, 2 \mathrm{H}), 7.62(\mathrm{~d}, J=8.6 \mathrm{~Hz}, 1 \mathrm{H}), 7.49$ (m, 1H), $7.45(\mathrm{~m}, 1 \mathrm{H}) .{ }^{13} \mathrm{C}$ NMR (101 MHz, DMSO-d6) $\delta$ $180.68,148.74,147.89,139.69,136.20,135.45,134.25$, $133.61,131.78,131.46,131.42,129.41,127.86,127.47$, $124.50,124.36$.

$N$-(3,4-difluorophenyl)- $N$ '-(4-pyridin-3-ylphenyl) thiourea (DATU7). HRMS $\mathrm{m} / z$ calcd for $\mathrm{C}_{18} \mathrm{H}_{13} \mathrm{~F}_{2} \mathrm{~N}_{3} \mathrm{~S}$ $\left([\mathrm{M}+\mathrm{H}]^{+}\right) 342.0876$, found 342.0851. m.p. $=139-140^{\circ} \mathrm{C}$, ${ }^{1} \mathrm{H}$ NMR (400 MHz, DMSO-d6) $\delta 10.12(\mathrm{~s}, 1 \mathrm{H}), 10.03$ (s, 1H), $8.92(\mathrm{~d}, J=1.8 \mathrm{~Hz}, 1 \mathrm{H}), 8.56(\mathrm{~m}, 1 \mathrm{H}), 8.11-8.07$ $(\mathrm{m}, 1 \mathrm{H}), 7.74(\mathrm{~d}, J=8.5 \mathrm{~Hz}, 2 \mathrm{H}), 7.70(\mathrm{~d}, J=2.5 \mathrm{~Hz}$, $1 \mathrm{H}), 7.62(\mathrm{~d}, J=8.6 \mathrm{~Hz}, 2 \mathrm{H}), 7.49(\mathrm{~m}, 1 \mathrm{H}), 7.46-7.38(\mathrm{~m}$, 1H), 7.29-7.24 (m, 1H). ${ }^{13} \mathrm{C}$ NMR (101 MHz, DMSO-d6) $\delta 180.18,148.67,147.83,139.79,136.86,135.51,134.31$, $133.49,127.46,124.48,124.38,120.88,117.55,117.37$, $113.72,113.52$.

$N$-(3,4-dichlorophenyl)- $N$ '-(4-pyridin-3-ylphenyl) thiourea (DATU8). HRMS $\mathrm{m} / \mathrm{z}$ calcd for $\mathrm{C}_{18} \mathrm{H}_{13} \mathrm{Cl}_{2} \mathrm{~N}_{3} \mathrm{~S}$ $\left([\mathrm{M}+\mathrm{H}]^{+}\right) 374.0285$, found 374.0258 . m.p. $=173-175^{\circ} \mathrm{C}$, ${ }^{1} \mathrm{H}$ NMR (400 MHz, DMSO-d6) $\delta 10.21$ (s, 1H), 10.10 (s, 1H), $8.91(\mathrm{~d}, J=1.9 \mathrm{~Hz}, 1 \mathrm{H}), 8.57(\mathrm{~m}, 1 \mathrm{H}), 8.12-8.07$ $(\mathrm{m}, 1 \mathrm{H}), 7.91(\mathrm{~d}, J=2.4 \mathrm{~Hz}, 1 \mathrm{H}), 7.74(\mathrm{~d}, J=8.6 \mathrm{~Hz}$, 2H), $7.62(\mathrm{~d}, J=4.1 \mathrm{~Hz}, 2 \mathrm{H}), 7.60$ (d, $J=4.2 \mathrm{~Hz}, 1 \mathrm{H})$, 7.52-7.49 (m, 1H), $7.47(\mathrm{~m}, 1 \mathrm{H}) .{ }^{13} \mathrm{C}$ NMR $(101 \mathrm{MHz}$, DMSO-d6) $\delta 179.97,148.72,147.87,140.21,139.68$, $135.48,134.30,133.61,130.91,130.68,127.50,126.45$, $125.27,124.49,124.38,124.05$.

$N$-[3,5-bis(trifluoromethyl)phenyl]-N'-(4-pyridin3-ylphenyl)thiourea (DATU9). HRMS $\mathrm{m} / \mathrm{z}$ calcd for $\mathrm{C}_{20} \mathrm{H}_{13} \mathrm{~F}_{6} \mathrm{~N}_{3} \mathrm{~S} \quad\left([\mathrm{M}+\mathrm{H}]^{+}\right)$442.0813, found 442.0791. m.p. $=157-158^{\circ} \mathrm{C},{ }^{1} \mathrm{H}$ NMR (400 MHz, DMSO-d6) $\delta 10.48$ (s, 1H), $10.35(\mathrm{~s}, 1 \mathrm{H}), 8.92(\mathrm{~d}, J=1.9 \mathrm{~Hz}, 1 \mathrm{H}), 8.61-8.55$ (m, 1H), 8.28 (s, 2H), 8.10 (d, $J=8.0 \mathrm{~Hz}, 1 \mathrm{H}), 7.83$ (s, $1 \mathrm{H}), 7.77(\mathrm{~d}, J=8.5 \mathrm{~Hz}, 2 \mathrm{H}), 7.61(\mathrm{~d}, J=8.5 \mathrm{~Hz}, 2 \mathrm{H})$, $7.50(\mathrm{~m}, 1 \mathrm{H}) .{ }^{13} \mathrm{C}$ NMR (101 MHz, DMSO-d6) $\delta 180.19$, 148.82, 147.93, 142.30, 139.23, 135.41, 134.31, 134.05, $130.64,130.31,127.71,127.20,125.07,124.75,124.38$, 124.04, 122.36, 117.43.
$N$-1,3-benzodioxol-5-yl-N'-(4-pyridin-3-ylphenyl) thiourea (DATU10). HRMS $m / z$ calcd for $\mathrm{C}_{19} \mathrm{H}_{15} \mathrm{~N}_{3} \mathrm{O}_{2} \mathrm{~S}$ $\left([\mathrm{M}+\mathrm{H}]^{+}\right) 350.0963$, found 350.0931. m.p. $=147-148^{\circ} \mathrm{C}$, ${ }^{1} \mathrm{H}$ NMR (400 MHz, DMSO-d6) $\delta 9.84(\mathrm{~s}, 1 \mathrm{H}), 9.79$ (s, $1 \mathrm{H}), 8.91(\mathrm{~d}, J=1.5 \mathrm{~Hz}, 1 \mathrm{H}), 8.60-8.53(\mathrm{~m}, 1 \mathrm{H}), 8.07$ $(\mathrm{d}, J=8.0 \mathrm{~Hz}, 1 \mathrm{H}), 7.71(\mathrm{~d}, J=8.5 \mathrm{~Hz}, 2 \mathrm{H}), 7.63(\mathrm{~d}, J=$ $8.5 \mathrm{~Hz}, 2 \mathrm{H}), 7.48(\mathrm{~m}, 1 \mathrm{H}), 7.12(\mathrm{~d}, J=1.4 \mathrm{~Hz}, 1 \mathrm{H}), 6.90$ $(\mathrm{d}, J=8.3 \mathrm{~Hz}, 1 \mathrm{H}), 6.82(\mathrm{~m}, 1 \mathrm{H}), 6.04(\mathrm{~s}, 2 \mathrm{H}) \cdot{ }^{13} \mathrm{C} \mathrm{NMR}$ (101 MHz, DMSO-d6) $\delta$ 180.21, 148.66, 147.86, 147.38, $144.98,140.17,135.54,134.19,133.69,133.15,127.29$, 124.42, 124.35, 118.11, 108.29, 106.95, 101.72 .

General Procedure for the Synthesis of quinazolinone diaryl urea derivatives QDAU1-10.

7-Bromoquinazolin-4(3H)-one (8). Around bottom two flask charged with 2-amino-5-bromobenzoicacid $7(5.00 \mathrm{~g}, 23.14 \mathrm{mmol})$ was flushed with nitrogen and suspended in $\mathrm{HCONH}_{2}(80 \mathrm{~mL}, 2.01 \mathrm{mmol})$, the mixture was stirred at $150^{\circ} \mathrm{C}$ for $1.5 \mathrm{~h}$ by atmospheric microwave heating. The product was extracted with AcOEt (50 $\mathrm{mL} \times 3$ ), washed with water, and dried over $\mathrm{Na}_{2} \mathrm{SO}_{4}$. After filtration and concentration in vacuo, the residue was purified by silica gel flash chromatography (PE/ AcOEt $=5: 1)$ affording $8(1.46 \mathrm{~g}, 41.24 \%)$ as white solid. mp: $259 \sim 261^{\circ} \mathrm{C}$.

1-(4-(4,4,5,5-tetramethyl-1,3,2-dioxaborolan2-yl)phenyl)-3-(3-(trifluoromethyl)phenyl)urea(10).

Triphosgene $(0.80 \mathrm{~g}, 2.74 \mathrm{mmol})$ was dissolved in anhydrous $\mathrm{CH}_{2} \mathrm{Cl}_{2}(20 \mathrm{~mL})$ and the mixture was stirred on the ice-bath for $5 \mathrm{~min}$. A solution of 3-(trifluoromethyl) aniline $(1.10 \mathrm{~g}, 6.85 \mathrm{mmol})$ in anhydrous $\mathrm{CH}_{2} \mathrm{Cl}_{2}$ was added dropwise to the above mixture and stirring was continued for $15 \mathrm{~min}$. Then triethanolamine $(1.15 \mathrm{~mL}, 8.22$ mmol) diluted with $\mathrm{CH}_{2} \mathrm{Cl}_{2}(10 \mathrm{~mL})$ was then added onto the mixture. Stirring was continued for $15 \mathrm{~min}$, a solution of triethanolamine $(1.15 \mathrm{~mL}, 8.22 \mathrm{mmol})$ and 4-(4,4,5,5-tetramethyl-1,3,2-dioxaborolan-2-yl)aniline $(1.50 \mathrm{~g}, 6.85 \mathrm{mmol})$ in anhydrous $\mathrm{CH}_{2} \mathrm{Cl}_{2}(10 \mathrm{~mL})$ was added and continued stirring for $20 \mathrm{~min}$. Subsequently, the ice bath was removed, and the mixture was reacted at room temperature overnight. After completion of the action, the reaction was quenched with dilute $\mathrm{NaHCO}_{3}$. The organic layer was washed and dried overNa $\mathrm{SO}_{4}$. After filtration and concentration in vacuo, the residue was purified by column chromatography $(\mathrm{PE} / \mathrm{AcOEt}=7: 1)$ affording 10 as white solid $(1.77 \mathrm{~g}, 63.67 \%)$.

1-(4-(4-oxo-3,4-dihydroquinazolin-7-yl)phenyl)-3(3-(trifluoromethyl)phenyl)urea (QDAU1). A flask charged with $\mathrm{Pd}\left(\mathrm{PPh}_{3}\right)_{4}(0.39 \mathrm{~g}, 0.34 \mathrm{mmol})$, potassium carbonate $(1.43 \mathrm{~g}, 10.35 \mathrm{mmol})$, and the key intermediate $10(1.40 \mathrm{~g}$, $3.45 \mathrm{mmol})$ and $8(0.78 \mathrm{~g}, 3.45 \mathrm{mmol})$ were flushed with nitrogen and suspended in 1,4-dioxane $(90 \mathrm{~mL})$ and water $(30 \mathrm{~mL})$. The mixture was then refluxed overnight under nitrogen. The hot suspension was filtered and the filtrate distilled by rotary evaporation to remove 1,4-dioxane. Water $(50 \mathrm{~mL})$ was added and the product was extracted with AcOEt $(30 \mathrm{~mL} \times 3)$, washed with water, and dried over 
$\mathrm{Na}_{2} \mathrm{SO}_{4}$. After filtration and concentration in vacuo, the residue was purified by silica gel flash chromatography $(\mathrm{PE} / \mathrm{AcOEt}=2: 1)$ affording QDAU1 $(0.21 \mathrm{~g})$ as white solid (yield 14.4\%), HRMS $m / z$ calcd for $\mathrm{C}_{22} \mathrm{H}_{15} \mathrm{~F}_{3} \mathrm{~N}_{4} \mathrm{O}_{2}\left([\mathrm{M}]^{+}\right)$ 424.1147, found 424.1158. m.p. $>300^{\circ} \mathrm{C},{ }^{1} \mathrm{H}$ NMR (400 MHz, DMSO-d6) $\delta 12.25$ (s, 1H), 9.15 (s, 1H), 9.05 (s, $1 \mathrm{H}), 8.17(\mathrm{~d}, \mathrm{~J}=8.3 \mathrm{~Hz}, 1 \mathrm{H}), 8.13(\mathrm{~s}, 1 \mathrm{H}), 8.05(\mathrm{~s}, 1 \mathrm{H})$, $7.91(\mathrm{~d}, \mathrm{~J}=1.5 \mathrm{~Hz}, 1 \mathrm{H}), 7.84(\mathrm{~m}, \mathrm{~J}=8.4,1.7 \mathrm{~Hz}, 1 \mathrm{H})$, $7.80(\mathrm{~d}, \mathrm{~J}=8.7 \mathrm{~Hz}, 2 \mathrm{H}), 7.64(\mathrm{~d}, \mathrm{~J}=8.8 \mathrm{~Hz}, 2 \mathrm{H}), 7.60$ (s, $1 \mathrm{H}), 7.54$ (t, J = 7.9 Hz, 1H), 7.34 (d, J = 7.6 Hz, 1H). ${ }^{13} \mathrm{C}$ NMR (101 MHz, DMSO-d6) $\delta 161.03,152.89,149.83$, $146.26,145.91,140.95,140.50,132.55,130.43,128.16$, $127.00,125.34,124.31,122.40,121.46,119.26,66.81$.

The title compounds QDAU2 -10 were prepared from the key intermediate 8 and 10 with a similar procedure as described for compound QDAU1.

1-(3-chlorophenyl)-3-(4-(4-oxo-3,4-

dihydroquinazolin-7-yl)phenyl)urea (QDAU2). White solid (yield 6.7\%), HRMS $m / z$ calcd for $\mathrm{C}_{21} \mathrm{H}_{15} \mathrm{ClN}_{4} \mathrm{O}_{2}$ $\left([\mathrm{M}+\mathrm{H}]^{+}\right)$391.0884, found 391.0923. m.p. $>300^{\circ} \mathrm{C},{ }^{1} \mathrm{H}$ NMR (400 MHz, DMSO-d6) $\delta 12.25$ (s, 1H), 8.99 (s, 2H), $8.16(\mathrm{~d}, \mathrm{~J}=7.8 \mathrm{~Hz}, 1 \mathrm{H}), 8.13(\mathrm{~s}, 1 \mathrm{H}), 7.87$ (d, J = 22.9 Hz, 2H), $7.76(\mathrm{~d}, \mathrm{~J}=16.8 \mathrm{~Hz}, 2 \mathrm{H}), 7.63$ (s, 2H), $7.31(\mathrm{~s}, 2 \mathrm{H})$, 7.04 (s, 1H). ${ }^{13} \mathrm{C}$ NMR (101 MHz, DMSO-d6) $\delta$ 161.03, $152.76,149.83,146.26,145.92,141.63,140.55,133.67$, $132.48,130.91,128.17,126.99,125.33,124.30,122.05$, $121.45,119.16,118.09,117.20$.

1-(3-fluorophenyl)-3-(4-(4-oxo-3,4-

dihydroquinazolin-7-yl)phenyl)ure (QDAU3). White solid (yield 24.6\%), HRMS $m / z$ calcd for $\mathrm{C}_{21} \mathrm{H}_{15} \mathrm{FN}_{4} \mathrm{O}_{2}$ $\left([\mathrm{M}+\mathrm{H}]^{+}\right) 375.1179$, found 375.1217. m.p. $>300^{\circ} \mathrm{C},{ }^{1} \mathrm{H}$ NMR (400 MHz, DMSO-d6) $\delta 12.25$ (s, 1H), 9.00 (s, 1H), 8.98 (s, 1H), 8.16 (d, J = 8.3 Hz, 1H), 8.13 (s, 1H), 7.90 (s, 1H), $7.83(\mathrm{~d}, \mathrm{~J}=8.4 \mathrm{~Hz}, 1 \mathrm{H}), 7.79(\mathrm{~d}, \mathrm{~J}=8.5 \mathrm{~Hz}, 2 \mathrm{H})$, $7.62(\mathrm{~d}, \mathrm{~J}=8.6 \mathrm{~Hz}, 2 \mathrm{H}), 7.52(\mathrm{~d}, \mathrm{~J}=11.9 \mathrm{~Hz}, 1 \mathrm{H}), 7.32$ $(\mathrm{m}, \mathrm{J}=15.3,7.9 \mathrm{~Hz}, 1 \mathrm{H}), 7.15(\mathrm{~d}, \mathrm{~J}=8.0 \mathrm{~Hz}, 1 \mathrm{H}), 6.81$ $(\mathrm{m}, \mathrm{J}=11.6,5.1 \mathrm{~Hz}, 1 \mathrm{H}) .{ }^{13} \mathrm{C}$ NMR (101 MHz, DMSO-d6) $\delta 161.68,161.03,152.75,149.83,146.25,145.92,140.56$, $132.47,130.87,130.77,128.17,126.99,125.32,124.30$, $121.45,119.14,114.46,108.84,105.54,105.27$.

1-(2-fluorophenyl)-3-(4-(4-oxo-3,4-

dihydroquinazolin-7-yl)phenyl)urea (QDAU4). White solid (yield 22.5\%), HRMS $\mathrm{m} / z$ calcd for $\mathrm{C}_{21} \mathrm{H}_{15} \mathrm{FN}_{4} \mathrm{O}_{2}$ $\left([\mathrm{M}+\mathrm{H}]^{+}\right) 375.1179$, found 375.1222. m.p. $>300^{\circ} \mathrm{C},{ }^{1} \mathrm{H}$ NMR (400 MHz, DMSO-d6) $\delta 9.81$ (s, 1H), 9.17 (s, 1H), $8.16(\mathrm{t}, \mathrm{J}=4.1 \mathrm{~Hz}, 2 \mathrm{H}), 8.15-8.10(\mathrm{~m}, 1 \mathrm{H}), 7.86(\mathrm{~d}, \mathrm{~J}$ $=1.2 \mathrm{~Hz}, 1 \mathrm{H}), 7.79(\mathrm{~s}, 1 \mathrm{H}), 7.77(\mathrm{~s}, 2 \mathrm{H}), 7.67(\mathrm{~d}, \mathrm{~J}=8.6$ $\mathrm{Hz}, 2 \mathrm{H}), 7.25$ (m, J = 10.9, $8.8 \mathrm{~Hz}, 1 \mathrm{H}), 7.16$ (t, J = 7.7 $\mathrm{Hz}, 1 \mathrm{H}), 7.04(\mathrm{~m}, \mathrm{~J}=9.2,6.5,1.5 \mathrm{~Hz}, 1 \mathrm{H}) .{ }^{13} \mathrm{C}$ NMR (101 MHz, DMSO-d6) $\delta 163.56,154.06,152.85,151.66$, $150.38,148.93,145.24,140.69,132.64,128.10,126.98$, $124.95,124.92,124.56,123.95,123.23,123.15,121.71$, $121.50,118.94,115.63,115.44$.

1-(3,4-difluorophenyl)-3-(4-(4-oxo-3,4dihydroquinazolin-7-yl)phenyl)urea (QDAU5). White solid (yield 27.2\%), HRMS $m / z$ calcd for $\mathrm{C}_{21} \mathrm{H}_{14} \mathrm{~F}_{2} \mathrm{~N}_{4} \mathrm{O}_{2}$
$\left([\mathrm{M}+\mathrm{H}]^{+}\right)$393.1085, found 393.1123. m.p. $>300^{\circ} \mathrm{C},{ }^{1} \mathrm{H}$ NMR (400 MHz, DMSO-d6) $\delta 12.25$ (s, 1H), 8.98 (s, 2H), $8.16(\mathrm{~d}, \mathrm{~J}=8.3 \mathrm{~Hz}, 1 \mathrm{H}), 8.12$ (s, 1H), 7.90 (d, J = 1.1 Hz, $1 \mathrm{H}), 7.86-7.81(\mathrm{~m}, 1 \mathrm{H}), 7.78(\mathrm{~d}, \mathrm{~J}=8.6 \mathrm{~Hz}, 2 \mathrm{H}), 7.70$ $(\mathrm{m}, \mathrm{J}=13.3,7.4,2.4 \mathrm{~Hz}, 1 \mathrm{H}), 7.61(\mathrm{~d}, \mathrm{~J}=8.7 \mathrm{~Hz}, 2 \mathrm{H})$, $7.36(\mathrm{~m}, \mathrm{~J}=19.5,9.3 \mathrm{~Hz}, 1 \mathrm{H}), 7.19-7.12(\mathrm{~m}, 1 \mathrm{H}) .{ }^{13} \mathrm{C}$ NMR (101 MHz, DMSO-d6) $\delta$ 161.03, 152.83, 149.83, $146.24,145.91,143.85,143.72,140.54,137.24,137.14$, $132.49,128.15,126.98,125.31,124.29,121.45,119.18$, $117.96,117.78,114.91,107.82,107.61$.

1-(4-fluorophenyl)-3-(4-(4-oxo-3,4-

dihydroquinazolin-7-yl)phenyl)urea (QDAU6). White solid (yield 19.1\%), HRMS $m / z$ calcd for $\mathrm{C}_{21} \mathrm{H}_{15} \mathrm{FN}_{4} \mathrm{O}_{2}$ $\left([\mathrm{M}+\mathrm{H}]^{+}\right) 375.1179$, found 375.1225 . m.p. $>300^{\circ} \mathrm{C},{ }^{1} \mathrm{H}$ NMR (400 MHz, DMSO-d6) $\delta 9.85$ (s, 1H), 9.77 (s, 1H), 8.19 (s, 1H), 8.17 (d, J = 8.6 Hz, 1H), $7.86(\mathrm{~d}, \mathrm{~J}=1.4 \mathrm{~Hz}$, $1 \mathrm{H}), 7.81-7.78(\mathrm{~m}, 1 \mathrm{H}), 7.76(\mathrm{~d}, \mathrm{~J}=3.1 \mathrm{~Hz}, 2 \mathrm{H}), 7.68(\mathrm{~d}$, $\mathrm{J}=8.7 \mathrm{~Hz}, 2 \mathrm{H}), 7.60-7.54(\mathrm{~m}, 2 \mathrm{H}), 7.14(\mathrm{t}, \mathrm{J}=8.9 \mathrm{~Hz}$, 2H). ${ }^{13} \mathrm{C}$ NMR (101 MHz, DMSO-d6) $\delta 158.90,156.54$, $153.34,150.45,149.15,145.29,141.13,136.87,132.32$, $127.99,126.95,124.53,123.87,121.40,120.47,120.40$, $119.01,115.80,115.58$.

1-(4-(4-oxo-3,4-dihydroquinazolin-7-yl)phenyl)-

3-(4-(trifluoromethoxy)phenyl)urea (QDAU7). White solid (yield 14.3\%), HRMS $m / z$ calcd for $\mathrm{C}_{22} \mathrm{H}_{15} \mathrm{~F}_{3} \mathrm{~N}_{4} \mathrm{O}_{3}$ $\left([\mathrm{M}+\mathrm{H}]^{+}\right) 441.1096$, found 441.1138 . m.p. $>300^{\circ} \mathrm{C},{ }^{1} \mathrm{H}$ NMR (400 MHz, DMSO-d6) $\delta 12.27$ (s, 1H), 9.47 (s, 1H), 9.44 (s, 1H), 8.16 (d, J = 8.3 Hz, 1H), 8.13 (s, 1H), 7.90 (s, 1H), $7.83(\mathrm{~d}, \mathrm{~J}=8.3 \mathrm{~Hz}, 1 \mathrm{H}), 7.79(\mathrm{~d}, \mathrm{~J}=8.5 \mathrm{~Hz}, 2 \mathrm{H})$, 7.63 (d, J = 8.6 Hz, 2H), 7.59 (d, J = 8.9 Hz, 2H), 7.30 $(\mathrm{d}, \mathrm{J}=8.4 \mathrm{~Hz}, 2 \mathrm{H}) .{ }^{13} \mathrm{C}$ NMR (101 MHz, DMSO-d6) $\delta$ 161.04, 152.98, 149.84, 146.25, 145.96, 143.02, 140.80, $139.51,132.24,128.16,126.98,125.30,124.24,122.25$, 121.40, 119.69, 119.40, 118.89 .

1-(3-isopropylphenyl)-3-(4-(4-oxo-3,4-

dihydroquinazolin-7-yl)phenyl)urea (QDAU8). White solid (yield 26.7\%), HRMS $m / z$ calcd for $\mathrm{C}_{24} \mathrm{H}_{22} \mathrm{~N}_{4} \mathrm{O}_{2}$ $\left([\mathrm{M}+\mathrm{H}]^{+}\right)$399.1743, found 399.1780. m.p. $>300^{\circ} \mathrm{C},{ }^{1} \mathrm{H}$ NMR (400 MHz, DMSO-d6) $\delta 12.25$ (s, 1H), 8.87 (s, 1H), $8.71(\mathrm{~s}, 1 \mathrm{H}), 8.17(\mathrm{~d}, \mathrm{~J}=8.3 \mathrm{~Hz}, 1 \mathrm{H}), 8.13(\mathrm{~s}, 1 \mathrm{H}), 7.90$ $(\mathrm{s}, 1 \mathrm{H}), 7.86-7.81(\mathrm{~m}, 1 \mathrm{H}), 7.78(\mathrm{~d}, \mathrm{~J}=8.6 \mathrm{~Hz}, 2 \mathrm{H}), 7.62$ $(\mathrm{d}, \mathrm{J}=8.7 \mathrm{~Hz}, 2 \mathrm{H}), 7.37$ (s, 1H), $7.28(\mathrm{~d}, \mathrm{~J}=8.6 \mathrm{~Hz}, 1 \mathrm{H})$, 7.20 (t, J = 7.8 Hz, 1H), 6.87 (d, J = 7.5 Hz, 1H), $2.85(\mathrm{~m}$, $\mathrm{J}=13.7,6.8 \mathrm{~Hz}, 1 \mathrm{H}), 1.20(\mathrm{~d}, \mathrm{~J}=6.9 \mathrm{~Hz}, 6 \mathrm{H}) .{ }^{13} \mathrm{C} \mathrm{NMR}$ (101 MHz, DMSO-d6) $\delta 161.03,152.90,149.84,149.52$, $146.24,145.97,140.90,139.99,132.15,129.17,128.13$, $126.99,125.29,124.23,121.40,120.52,118.95,116.72$, $116.38,33.97,24.35$.

1-(4-chloro-3-(trifluoromethyl)phenyl)-3-(4-(4-oxo3,4-dihydroquinazolin-7-yl)phenyl)urea (QDAU9). White solid (yield 12.7\%), HRMS $m / z$ calcd for $\mathrm{C}_{22} \mathrm{H}_{14} \mathrm{ClF}_{3} \mathrm{~N}_{4} \mathrm{O}_{2}$ $\left([\mathrm{M}+\mathrm{H}]^{+}\right)$459.0757, found 459.0786. m.p. $>300^{\circ} \mathrm{C},{ }^{1} \mathrm{H}$ NMR (400 MHz, DMSO-d6) $\delta 12.26$ (s, 1H), 9.64 (s, $1 \mathrm{H}), 9.39$ (s, 1H), $8.16(\mathrm{~d}, \mathrm{~J}=8.4 \mathrm{~Hz}, 1 \mathrm{H}), 8.13$ (s, 2H), $7.90(\mathrm{~s}, 1 \mathrm{H}), 7.83(\mathrm{~d}, \mathrm{~J}=8.4 \mathrm{~Hz}, 1 \mathrm{H}), 7.79(\mathrm{~d}, \mathrm{~J}=8.5 \mathrm{~Hz}$, $2 \mathrm{H}), 7.65(\mathrm{~d}, \mathrm{~J}=4.1 \mathrm{~Hz}, 2 \mathrm{H}), 7.63(\mathrm{~d}, \mathrm{~J}=6.5 \mathrm{~Hz}, 2 \mathrm{H}) .{ }^{13} \mathrm{C}$ 
NMR (101 MHz, DMSO-d6) $\delta 161.03,152.87,149.83$, $146.26,145.89,140.41,139.81,132.51,128.17,126.98$, $125.32,124.31,123.38,122.73,121.46,119.20,66.81$. 1-(4-(4-oxo-3,4-dihydroquinazolin-7-yl)phenyl)3-(4-(trifluoromethyl)phenyl)urea (QDAU10). White solid (yield 15.1\%), HRMS $\mathrm{m} / \mathrm{z}$ calcd for $\mathrm{C}_{22} \mathrm{H}_{15} \mathrm{~F}_{3} \mathrm{~N}_{4} \mathrm{O}_{2}$ $\left([\mathrm{M}+\mathrm{H}]^{+}\right) 425.1147$, found 425.1181 . m.p. $>300^{\circ} \mathrm{C},{ }^{1} \mathrm{H}$ NMR (400 MHz, DMSO-d6) $\delta 12.25$ (s, 1H), 9.20 (s, 1H), $9.04(\mathrm{~s}, 1 \mathrm{H}), 8.17$ (d, J = 8.3 Hz, 1H), 8.13 (s, 1H), 7.90 (s, 1H), $7.82(\mathrm{~d}, \mathrm{~J}=9.1 \mathrm{~Hz}, 1 \mathrm{H}), 7.79(\mathrm{~d}, \mathrm{~J}=8.5 \mathrm{~Hz}, 2 \mathrm{H})$, $7.70(\mathrm{~d}, \mathrm{~J}=8.6 \mathrm{~Hz}, 2 \mathrm{H}), 7.64(\mathrm{~d}, \mathrm{~J}=8.1 \mathrm{~Hz}, 3 \mathrm{H}), 7.47$ $(\mathrm{d}, \mathrm{J}=8.1 \mathrm{~Hz}, 1 \mathrm{H}) .{ }^{13} \mathrm{C}$ NMR (101 MHz, DMSO-d6) $\delta$ $161.04,152.66,149.82,146.24,145.89,143.82,140.43$, $132.63,128.17,126.99,126.54,125.31,124.32,123.67$, $122.49,122.17,121.47,119.22,118.39$.

\section{CONCLUSIONS}

In summary, two classes of twenty multi-target RTKIs have been developed with promising activity on angiogenic and oncogenic VEGFR-2, Tie-2, and EphB4. Since all three RTKs play essential roles in both angiogenesis and tumorigenesis. These multiple RTKIs with a 'triplet' inhibition profile might have a major advantage of overcoming the compensatory feedback that characterizes single-target drugs. In vitro RTKs inhibition assay and molecular docking revealed that these compounds could suppress VEGFR-2, Tie-2, and EphB4 kinase activity through preferential binding at the ATP-binding site. Biological evaluation using different models led to the discovery of a biphenyl-aryl urea bearing a quinazolin-4(3H)-one moiety (QDAU5), which displayed both anti-angiogenic and anticancer activities. Moreover, quinazolin-4(3H)-one has been identified as an excellent hinge binding group for multi-target inhibitors of VEGFR-2, Tie-2, and EphB4. Further detailed mechanism of action study and extensive pharmacokinetics evaluation of QDAU5 are in progress and will be reported in due course.

\section{Abbreviations}

Ang, angiopoietin; DFG, aspartate-phenylalanineglycine; EC, epithelial cell; EGFR, epidermal growth factor receptor; Eph, erythropoietin-producing hepatoma; FGFR, fibroblast growth factor receptor; HATU, [bis(dimethylamino)methylene]-1H-1,2,3-triazolo [4,5b]pyridinium 3-oxide hexafluorophosphate; HBG, hinge binding group; HECs, Human endothelial cell; KDR, kinase insert domain receptor; RTK, receptor tyrosine kinase; RTKI, receptor tyrosine kinase inhibitor; Tie2, tyrosine kinase with Ig and epidermal growth factor homology domain-2; VEGFR-2, vascular endothelial growth factor receptor-2.

\section{Author contributions}

*Lin Zhang and Yuanyuan Shan contributed equally to this work and should be regarded as joint first authors.

The manuscript was written through contributions of all authors. All authors have given approval to the final version of the manuscript.

\section{ACKNOWLEDGMENTS AND FUNDING}

The research described here was supported by the National Natural Science Foundation of China (NSFC, Grant No. 81573285) and the Fundamental Research Funds for the Central Universities (2015qngz13). We gratefully acknowledge the use of Orion that is supported by Georgia State University's Research Solutions and the free academic licensing program of Openeye. This work used the Extreme Science and Engineering Discovery Environment (XSEDE), which is supported by National Science Foundation grant number ACI-1053575.

\section{CONFLICTS OF INTEREST}

The authors declare no conflicts of interest.

\section{REFERENCES}

1. Pandya NM, Dhalla NS, Santani DD. Angiogenesis--a new target for future therapy. Vascul Pharmacol. 2006; 44: 265 274.

2. Muz B, de la Puente P, Azab F, Azab AK. The role of hypoxia in cancer progression, angiogenesis, metastasis, and resistance to therapy. Hypoxia (Auckl). 2015; 3: 83-92.

3. Folkman J. Tumor angiogenesis: therapeutic implications. N Engl J Med. 1971; 285: 1182-1186.

4. Weis SM, Cheresh DA. Tumor angiogenesis: molecular pathways and therapeutic targets. Nat Med. 2011; 17: 13591370.

5. Bouïs D, Kusumanto Y, Meijer C, Mulder NH, Hospers GA. A review on pro- and anti-angiogenic factors as targets of clinical intervention. Pharmacol Res. 2006; 53: 89-103.

6. Himanen JP, Rajashankar KR, Lackmann M, Cowan CA, Henkemeyer M, Nikolov DB. Crystal structure of an Eph receptor-ephrin complex. Nature. 2001; 414: 933-938.

7. Hanahan D, Folkman J. Patterns and emerging mechanisms of the angiogenic switch during tumorigenesis. Cell. 1996; 86: 353-364.

8. Lu W, Li P, Shan Y, Su P, Wang J, Shi Y, Zhang J. Discovery of biphenyl-based VEGFR-2 inhibitors. Part 3: design, synthesis and 3D-QSAR studies. Bioorg Med Chem. 2015; 23: 1044-1054.

9. Su P, Wang J, Shi Y, Pan X, Shao R, Zhang J. Discovery of biphenyl-aryl ureas as novel VEGFR-2 inhibitors. Part 4: exploration of diverse hinge-binding fragments. Bioorg 
Med Chem. 2015; 23: 3228-3236.

10. Shan Y, Gao H, Shao X, Wang J, Pan X, Zhang J. Discovery of novel VEGFR-2 inhibitors. Part 5: Exploration of diverse hinge-binding fragments via core-refining approach. Eur J Med Chem. 2015; 103: 80-90.

11. Dai B, Qi J, Liu R, Zhang J, Zhan Y, Zhang Y. A novel compound T7 (N-\{4'-[(1E)-N-hydroxyethanimidoyl]3',5,6-trimethoxybiphenyl-3-yl\}-N'-[4-(3-morpholin-4ylpropoxy)phenyl]urea) screened by tissue angiogenesis model and its activity evaluation on anti-angiogenesis. Phytomedicine. 2014; 21: 1675-1683.

12. Peng YH, Shiao HY, Tu CH, Liu PM, Hsu JT, Amancha PK, Wu JS, Coumar MS, Chen CH, Wang SY, Lin WH, Sun HY, Chao YS, et al. Protein kinase inhibitor design by targeting the Asp-Phe-Gly (DFG) motif: the role of the DFG motif in the design of epidermal growth factor receptor inhibitors. J Med Chem. 2013; 56: 3889-3903.

13. Vijayan RS, He P, Modi V, Duong-Ly KC, Ma H, Peterson JR, Dunbrack RL Jr, Levy RM. Conformational analysis of the DFG-out kinase motif and biochemical profiling of structurally validated type II inhibitors. J Med Chem. 2015; 58: 466-479.

14. Sawamiphak S, Seidel S, Essmann CL, Wilkinson GA, Pitulescu ME, Acker T, Acker-Palmer A. Ephrin-B2 regulates VEGFR2 function in developmental and tumour angiogenesis. Nature. 2010; 465: 487-491.

15. Wang $Y$, Nakayama M, Pitulescu ME, Schmidt TS, Bochenek ML, Sakakibara A, Adams S, Davy A, Deutsch U, Lüthi U, Barberis A, Benjamin LE, Mäkinen T, et al. Ephrin-B2 controls VEGF-induced angiogenesis and lymphangiogenesis. Nature. 2010; 465: 483-486.

16. Nakayama M, Nakayama A, van Lessen M, Yamamoto H, Hoffmann S, Drexler HC, Itoh N, Hirose T, Breier G, Vestweber D, Cooper JA, Ohno S, Kaibuchi K, et al. Spatial regulation of VEGF receptor endocytosis in angiogenesis. Nat Cell Biol. 2013; 15: 249-260.

17. Yang X, Zhang Y, Yang Y, Lim S, Cao Z, Rak J, Cao Y. Vascular endothelial growth factor-dependent spatiotemporal dual roles of placental growth factor in modulation of angiogenesis and tumor growth. Proc Natl Acad Sci U S A. 2013; 110: 13932-13937.

18. Gacche RN. Compensatory angiogenesis and tumor refractoriness. Oncogenesis. 2015; 4: e153.

19. Dietrich J, Hulme C, Hurley LH. The design, synthesis, and evaluation of 8 hybrid DFG-out allosteric kinase inhibitors: a structural analysis of the binding interactions of Gleevec, Nexavar, and BIRB-796. Bioorg Med Chem. 2010; 18: 5738-5748.

20. Pan X, Wang F, Zhang Y, Gao H, Hu Z, Wang S, Zhang J. Design, synthesis and biological activities of Nilotinib derivates as antitumor agents. Bioorg Med Chem. 2013; 21: 2527-2534.

21. Daydé-Cazals B, Fauvel B, Singer M, Feneyrolles C, Bestgen B, Gassiot F, Spenlinhauer A, Warnault P, Van
Hijfte N, Borjini N, Chevé G, Yasri A. Rational Design, Synthesis, and Biological Evaluation of 7-Azaindole Derivatives as Potent Focused Multi-Targeted Kinase Inhibitors. J Med Chem. 2016; 59: 3886-3905.

22. Wang S, Chen J, Fu Y, Chen X. Promotion of Astragaloside IV for EA-hy926 Cell Proliferation and Angiogenic Activity via ERK1/2 Pathway. J Nanosci Nanotechnol. 2015; 15: 4239-4244.

23. Zheng L, He X, Ma W, Dai B, Zhan Y, Zhang Y. Ta1722, an anti-angiogenesis inhibitor targeted on VEGFR-2 against human hepatoma. Biomed Pharmacother. 2012; 66: 499505 .

24. Hou X, Wang S, Zhang T, Ma J, Zhang J, Zhang Y, Lu $\mathrm{W}, \mathrm{He} \mathrm{H}, \mathrm{He} \mathrm{L}$. Recent advances in cell membrane chromatography for traditional Chinese medicines analysis. J Pharm Biomed Anal. 2014; 101: 141-150.

25. Li M, Wang S, Zhang Y, He L. An online coupled cell membrane chromatography with LC/MS method for screening compounds from Aconitum carmichaeliDebx. acting on VEGFR-2. J Pharm Biomed Anal. 2010; 53: 1063-1069.

26. Du H, Lv N, Wang S, He L. Rapid characterization of a novel taspine derivative-HMQ1611 binding to EGFR by a cell membrane chromatography method. Comb Chem High Throughput Screen. 2013; 16: 324-329.

27. Kashem MA, Nelson RM, Yingling JD, Pullen SS, Prokopowicz AS 3rd, Jones JW, Wolak JP, Rogers GR, Morelock MM, Snow RJ, Homon CA, Jakes S. Three mechanistically distinct kinase assays compared: Measurement of intrinsic ATPase activity identified the most comprehensive set of ITK inhibitors. J Biomol Screen. 2007; 12: 70-83.

28. Shi HB, Chen JD, Chen XH, He Y, Yang ZJ. Effects of salvianolic acid and notoginsengtriterpenes on angiogenesis in EA-hy926 cells in vitro. Chin J Nat Med. 2013; 11: 254257.

29. Zhang Y, Zhang J, Dai B, Wang N, He L. Anti-proliferative and apoptotic effects of the novel taspine derivative tas 41 in the Caco-2 cell line. Environ Toxicol Pharmacol. 2011; 31: 406-415.

30. Zhan Y, Zhang Y, Liu C, Zhang J, Smith WW, Wang $\mathrm{N}$, Chen Y, Zheng L, He L. A novel taspine derivative, HMQ1611, inhibits breast cancer cell growth via estrogen receptor $\alpha$ and EGF receptor signaling pathways. Cancer Prev Res (Phila). 2012; 5: 864-873.

31. OpenEye Scientific Software, S. F., NM http://www. eyesopen.com/OMEGA version 2.5.1.4.

32. Hawkins PC, Skillman AG, Warren GL, Ellingson BA, Stahl MT. Conformer generation with OMEGA: algorithm and validation using high quality structures from the Protein Databank and Cambridge Structural Database. J Chem Inf Model. 2010; 50: 572-584.

33. OpenEye Scientific Software, S. F.; NM http://www. eyesopen.com/OEDocking version 3.2.0.2. 
34. Kayser M, Brauer S, Stoneking M. A genome scan to detect candidate regions influenced by local natural selection in human populations. Mol Biol Evol. 2003; 20: 893-900.

35. Sarajlic S, Edirisinghe N, Lukinov Y, Walters M, Davis B, Faroux G. Orion: Discovery Environment for HPC Research and Bridging XSEDE Resources. In Proceedings of the XSEDE16 Conference on Diversity, Big Data, and Science at Scale, ACM: Miami, USA, 2016; 1-5.
36. Towns J, Cockerill T, Dahan M, Foster I, Gaither K, Grimshaw A, Hazlewood V, Lathrop S, Lifka D, Peterson GD. XSEDE: accelerating scientific discovery. IEEE Comput. Sci. Eng. 2014; 16: 62-74. 